\title{
Biological links between traumatic brain injury and Parkinson's disease
}

Vedad Delic ${ }^{1,2^{*}}$, Kevin D. Beck ${ }^{2,3}$, Kevin C. H. Pang ${ }^{2,3}$ and Bruce A. Citron ${ }^{1,3}$

\begin{abstract}
Parkinson's Disease (PD) is a progressive neurodegenerative disorder with no cure. Clinical presentation is characterized by postural instability, resting tremors, and gait problems that result from progressive loss of A9 dopaminergic neurons in the substantia nigra pars compacta. Traumatic brain injury (TBI) has been implicated as a risk factor for several neurodegenerative diseases, but the strongest evidence is linked to development of PD. Mild $\mathrm{TBI}(\mathrm{mTBl})$, is the most common and is defined by minimal, if any, loss of consciousness and the absence of significant observable damage to the brain tissue. mTBI is responsible for a $56 \%$ higher risk of developing PD in U.S. Veterans and the risk increases with severity of injury. While the mounting evidence from human studies suggests a link between TBI and PD, fundamental questions as to whether TBI nucleates PD pathology or accelerates PD pathology in vulnerable populations remains unanswered. Several promising lines of research point to inflammation, metabolic dysregulation, and protein accumulation as potential mechanisms through which TBI can initiate or accelerate PD. Amyloid precursor protein (APP), alpha synuclein (a-syn), hyper-phosphorylated Tau, and TAR DNA-binding protein 43 (TDP-43), are some of the most frequently reported proteins upregulated following a TBI and are also closely linked to PD. Recently, upregulation of Leucine Rich Repeat Kinase 2 (LRRK2), has been found in the brain of mice following a TBI. Subset of Rab proteins were identified as biological substrates of LRRK2, a protein also extensively linked to late onset PD. Inhibition of LRRK2 was found to be neuroprotective in PD and TBI models. The goal of this review is to survey current literature concerning the mechanistic overlap between TBI and PD with a particular focus on inflammation, metabolic dysregulation, and aforementioned proteins. This review will also cover the application of rodent TBI models to further our understanding of the relationship between TBI and PD.
\end{abstract}

\section{Introduction}

TBI has been implicated as a risk factor for several neurodegenerative diseases, including Alzheimer's disease (AD), Amyotrophic Lateral Sclerosis (ALS), and PD [148]. Compelling evidence from three prospective cohort studies aimed at determining the relationship between TBI, AD, and PD supports the relationship

\footnotetext{
* Correspondence: vedad.delic@rutgers.edu

'Laboratory of Molecular Biology, VA New Jersey Health Care System,

Research and Development (Mailstop 15), 385 Tremont Ave, East Orange, NJ 07018, USA

${ }^{2}$ NeuroBehavioral Research Laboratory, VA New Jersey Health Care System, Research and Development (Mailstop 15), 385 Tremont Ave, East Orange, NJ 07018, USA

Full list of author information is available at the end of the article
}

between TBI and PD pathology [8, 9, 30, 76]. Analysis of aggregate neuropathological data gathered from Adult Changes in Thought study, the Religious Orders Study, and the Memory and Aging Project, all prospective studies, indicate that TBI is associated with a risk for Lewy body accumulation, parkinsonism, and PD and that TBI is not associated with dementia and AD pathology [30]. Furthermore, a recent study has shown that Veterans with a history of mTBI are at a 56\% higher risk for developing $\mathrm{PD}$ later in life and that this risk grows with increased TBI severity [45]. According to the CDC, an estimated 1.7 million people sustain a TBI annually in the U.S., and approximately $20 \%$ of returning service personnel are affected by TBI, totaling 320,000 soldiers 
since 2000 [106]. The high prevalence of TBI and its role as a risk factor for PD is a significant cause for concern.

Men account for the majority of TBIs in the U.S. and are also twice as likely to be diagnosed with PD [108, 151]. Although the sex differences are not fully understood, some studies suggest that estrogen could be responsible for the neuroprotection and milder symptoms seen at the onset of PD developing in women $[19,49]$. Other studies report that the progression of PD after onset is more aggressive in women than men which calls the estrogen explanation into question $[10,26,130]$. While the influence of sex on PD remains under investigation, less is known about the mechanistic contributions of TBI that could lead to eventual PD pathology.

In the general U.S. population, diagnosis of PD in individuals over the age of 45 is estimated to reach 930,000 by 2020 and $1,238,000$ by 2030 [98], forecasting a significant long-term disability cost to patients and their communities. Treatments beyond palliative care are not yet available for either PD or long-term consequences of TBI nor are there interventions known to slow down or prevent $\mathrm{PD}$ in at risk populations. Understanding the mechanistic relationship between PD and TBI will help inform future studies toward effective treatments and preventions. The following sections will contextualize disease overlap between PD and the neuropathology observed following TBI, highlight the most common types of TBI models and their applications in PD research, and discuss the next steps necessary to help determine points of intervention that may prevent PD from developing after TBI.

\section{Pathology overlap between TBI and PD}

TBI sequalae can be divided in to 3 phases: acute (0 to 1 week), post-acute (1 week to 1 month), and chronic (1 month to years). During the acute period cell necrosis from direct transfer of force to the brain tissue occurs, followed by secondary cell death from axonal pathology, and inflammation. The post-acute period can be characterized by neuronal remodeling, decreased inflammation, and an increase in chronic pathology [89]. Chronic pathology of most interest here includes, neurodegeneration, protein misfolding ( $\alpha$-syn, APP, Tau, TDP43), and persistent inflammation. Chronic TBI pathology can vary, with some patients recovering completely while others suffer physical and cognitive decline, and eventually develop neurodegenerative diseases [146], most notably Parkinson's Disease (PD) [30].

$\mathrm{PD}$ is the most prevalent movement disorder for which TBI is a major non-genetic risk factor [30, 61]. PD affects the entire basal ganglia, and is classically characterized by dopamine dysregulation in the nigrostriatal circuit, neuronal mitochondrial dysfunction, loss of dopaminergic projections to the striatum from the
Substantia Nigra pars compacta $(\mathrm{SNpc})$, culminating in progressive death of A9 dopaminergic neurons (DNs). A9 DNs of the SNpc are selectively lost in PD, while adjacent A10 DNs in the ventral tegmental area (VTA) are spared. This interesting selective loss of A9 neurons in PD is not yet fully understood, but it could be attributed to the A9 DN size, and higher expression of mitochondrial and metabolic proteins compared to other DNs [24]. Although motor symptoms remain cardinal signs associated with clinical PD, more recent clinical findings show that early PD pathology can cause non-motor symptoms that significantly impact life quality of patients.

Excessive salivation, constipation, forgetfulness, hyposmia and urinary urgency are common non-motor symptoms present in early PD that worsen with progression of the disease [71]. The most common psychotic phenomenon associated with PD are minor visual hallucinations [81]. Fourty to fifty percent of PD patients also develop anxiety which can occur at any stages of the disease $[80,120]$. Emerging evidence suggests that PD related pathology may occur in the peripheral nervous system (PNS), but due to lack of drug-naïve groups it is difficult to distinguish if the PNS neuropathology is a consequence of PD or pharmacological PD treatments [27]. In light of wide-ranging non-motor symptoms, and presence of pathology outside of the CNS, PD is increasingly considered a systemic rather than a disease of basal ganglia. Non-motor symptoms and pathology in the PNS, therefore, deserve additional consideration when studying PD pathology spread in humans and in animal models and during development of PD therapeutics.

PD during life is well defined by a combination of motor and non-motor symptoms, but the only definitive diagnosis remains by autopsy. Presence of intracellular proteinaceous Lewy Body inclusions and thread-like Lewy neurites are required for definitive postmortem diagnosis of PD. Originally, Lewy Body and Lewy neurite pathology was visualized using antibodies raised against ubiquitin, but subsequent study by Spillantini et al (1998) demonstrated that the PD inclusions were made up predominantly of misfolded and aggregated $\alpha$-syn protein [143]. Distinguishing posttranslational modification of the normally soluble and abundant $\alpha$-syn is hyper phosphorylation at the serine 129 residue [43]. Within neurons, $\alpha$-syn is normally localized to the synapse and the nucleus but the exact function of $\alpha$-syn is not yet known. These inclusions do not spread indiscriminately and are found in susceptible neurons that share some common traits. Neurons that appear to be protected are extensively myelinated projection neurons with long or short axons and those that are vulnerable are incompletely myelinated metabolically demanding projection neurons with long and thin axons [14]. It would be of interest to determine if the same neuron types are made 
more susceptible to PD pathology following diffuse axonal injury caused by mild or repetitive TBI.

Cause of $\alpha$-syn pathology nucleation remains unknown, but Braak hypothesized that an as of yet unknown pathogen could gain access to the central nervous system through the mucosa and neurons of the gut and the nasal cavity and nucleate PD pathology in those areas [51, 52]. According to the Braak hypothesis, a pathogen can gain entry into the CNS in one of two ways. One way is through the gut via the vagus nerve where the pathogen can nucleate $\alpha$-syn pathology that then spreads up the brain stem to the $\mathrm{SNpc}$ and the other is through the nasal mucosa via the olfactory neurons [14]. From these locations, the pathology can spread sequentially over time through vulnerable neurons. Analysis of postmortem idiopathic PD brains by Braak and Braak (2003) lead to the development of PD pathology staging that continues to be widely used by physicians and scientists [13]. The staging assumes that PD pathology does not originate simultaneously in all the affected brain areas, that the pathology burden is lower early in the disease and progresses over time through interconnected susceptible neurons. The 6 Braak stages are organized based on lesion location and inclusion pathology, with stages 1-2 having the lowest PD pathology burden with inclusions confined to the medulla oblongota and stages 5-6 having the highest pathology burden with significant brain involvement including the neocortical areas [13]. Braak staging has been confirmed with a study reporting 12 percent of clinical PD cases classified as Braak stage 3 and 88 percent of clinical PD cases as having Braak stages 4-6 [62]. $\alpha$-syn pathology was also found in the spinal and peripheral autonomic nervous system of 98 elderly patients without PD symptoms, suggesting that the earliest PD pathology may occur in the periphery and the spinal cord [12]. Braak hypothesis and staging however are not without their criticism. Because Braak hypothesis and Braak staging are based on the study of postmortem tissue from patients with young onset and long duration of the disease, Braak hypothesis and staging may only reflecta subset of PD cases [127].

Further evidence supporting the importance of $\alpha$-syn in pathogenesis of PD is provided by rare familial mutations within the alpha synuclein gene (SNCA) that result in aggressive early onset PD [72, 75, 82, 118, 167]. In addition to the missense mutations, duplications and triplications in an otherwise normal SNCA gene can also cause PD [21, 57, 85]. Post mortem analysis of PD patient brains who underwent bilateral fetal mesencephalic tissue transplantation, showed phospho-serine $129 \alpha$-syn positive Lewy Body inclusions in the grafted tissue, indicating trans-neuronal spread from recipient tissue to naïve donor tissue [83]. These findings also implicate abnormal $\alpha$-syn as a key player in the pathogenesis and pathology of PD. Mutations in other genes are also known to contribute to the development of PD with Lewy Body pathology. These include mutations in PARK2 (Parkin), PTEN-induced putative kinase 1 (PINK1), DJ-1, ATP13A2, and leucine-rich repeat kinase 2 (LRRK2) [32, 74].

PD as well as TBI brains are characterized by neuronal degeneration, compromised blood brain barrier, infiltration and expansion of resident microglia into the affected areas, and infiltration of phagocytic cells from the periphery (Fig. 1). In both PD and following a TBI this histological presentation is accompanied by inflammation, metabolic disturbances, and protein aggregation, making them essential factors to consider when studying the mechanisms connecting these two disorders.

\section{Inflammation}

Markers of inflammation are present in postmortem human brains years after TBI and are also present in brains of PD patients [123, 159]. Brains examined by positron emission tomography (PET) following head trauma for an activated microglial marker, showed an increase in activated microglia up to 17 years after a TBI, which was found to be associated with impaired information processing [123]. Inflammation occurs shortly after initial TBI event (acute sequalae), and can persist for years (chronic sequalae) in the affected areas [134]. Therefore, inflammation can be seen as a "chronic response to an acute event."

Similarly, persistent inflammation was found in PD patients with increased reactive microglia in the $\mathrm{SNpc}$ [101]. Major Histocompatibility Complex II (MHCII), normally not expressed in the brain, has been found in postmortem brains of PD patients [101]. MHCII is an important regulator of cellular innate immunity which also presents antigens to $\mathrm{T}$ and $\mathrm{B}$ lymphocytes of the adaptive immune system. CD8+ "killer" T cells are cytotoxic and can kill other infected or damaged cells. CD8+ $\mathrm{T}$ cells can recruit additional immune cells through the release of cytokines. B lymphocytes activated by MHCII and $\mathrm{T}$ cells, differentiate into memory $\mathrm{B}$ cells that retain information on the antigen, and undergo further maturation and expansion into antibody producing plasma cells. In the early stages of PD, MHCII expression correlates with toxic intracellular $\alpha$-syn aggregation in neurons, suggesting that prior to cell death $\alpha$-syn aggregation may be an important mediator of the immune response [58]. The number of activated microglia increases in the subtantia nigra with progression of PD and activated microglia are also found in other affected brain areas [132]. Unfortunately, detailed study of human PD and TBI brain inflammation remain limited to 


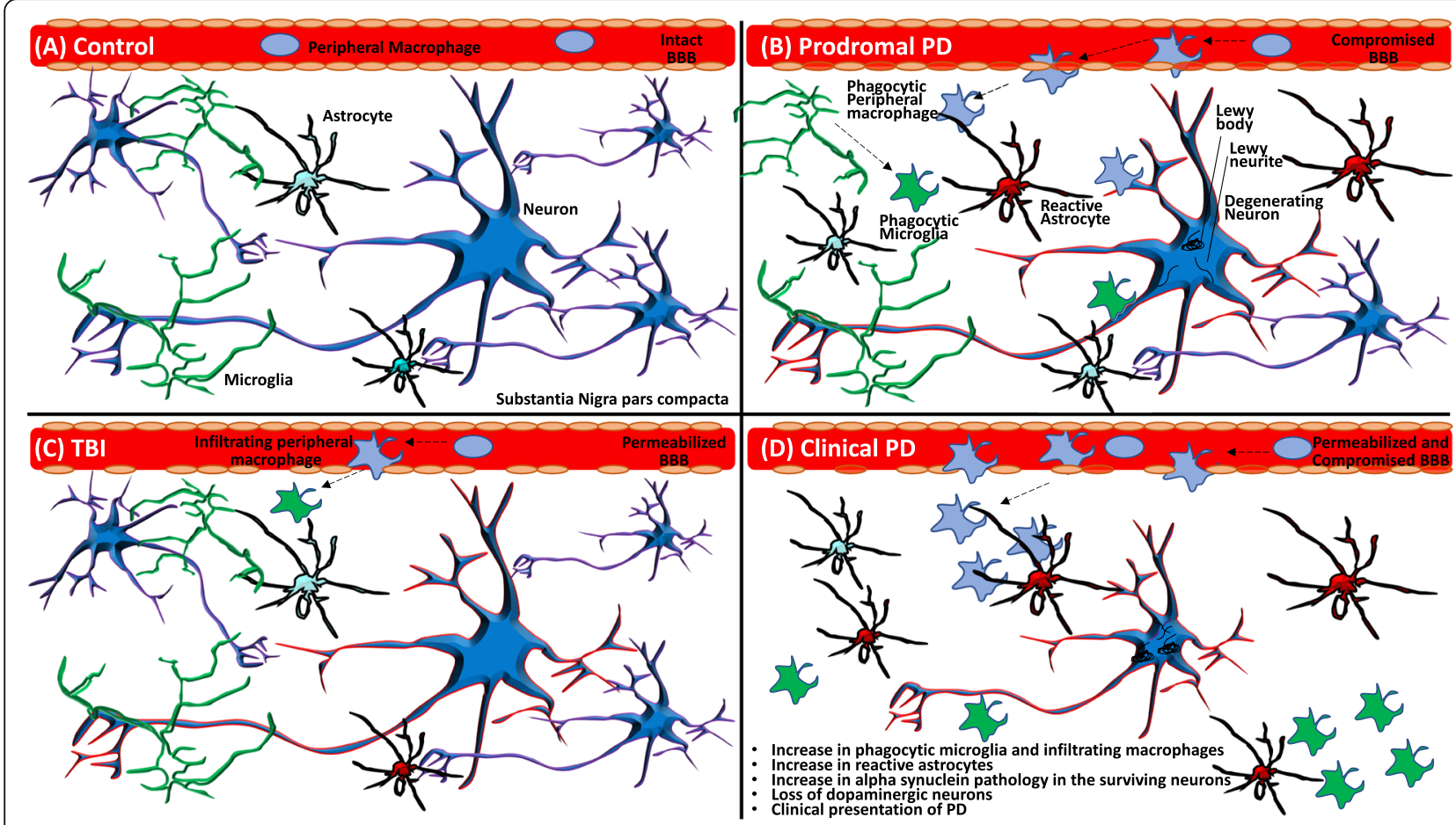

Figure 1 Potential influences of TBI on the course of PD. In the healthy brain the blood brain barrier (BBB) is intact, microglia are highly ramified and astrocytes are non-reactive and provide nourishment to neurons (a). In prodromal PD, degenerating neurons develop alpha synuclein pathology in the form of Lewy bodies and Lewy neurites, microglia become more amoeboid and phagocytic, BBB is compromised and peripheral immune cells infiltrate the brain where they become activated and take on a role similar to that of phagocytic resident microglia (b). After a TBI, BBB is temporarily permeabilized allowing infiltration of the peripheral immune cells, astrocytes become reactive and some neurons degenerate (c). In the clinical PD, the substantia nigra pars compacta is almost entirely devoid of dopaminergic neurons, and surviving neurons in nigra and other affected brain areas are burdened with alpha synuclein pathology while the areas vacated by dying neurons are filled with reactive astrocytes, microglia, and peripheral immune cells (d). Overlap in pathology induced by TBI and present in prodromal PD may allow for TBI to accelerate prodromal PD to clinical PD.

postmortem tissue necessitating reliance on animal models.

Templated prion-like conformational change of $\alpha$-syn into oligomers and higher ordered structures is supported by abundant In vitro and in vivo evidence [93]. Most compelling evidence for the $\alpha$-syn prion-like hypothesis comes from primate and rodent studies where primate or rodent brains were injected with misfolded $\alpha$-syn from different sources and subsequently developed PD-like pathology. In these studies, $\alpha$-syn PD-like pathology was induced by injection of human PD patient brain homogenate $[124,125]$, brain homogenate from transgenic animals that developed $\alpha$-syn pathology [110], or injection of transgenic and non-transgenic animals with recombinant $\alpha$-syn fibrils [92, 116, 129, 139]. These studies provide a direct line of evidence for $\alpha$-syn pathogenic templating from human PD patient brain homogenate containing misfolded $\alpha$-syn to transgenic animal models that demonstrate oligomeric $\alpha$-syn toxicity, and finally a synthetic $\alpha$-syn fibrils that can nucleate PD pathology. Together, these human and animal studies have paved the way for more controlled interrogation of $\alpha$-syn driven PD pathology. For additional information on $\alpha$-syn fibril and other PD models we direct the reader to a review by Volpicelli-Daley et al [157].

Using synthetic fibrilized $\alpha$-syn, MHCII expression in rats, like in humans, has been shown to persist after dopaminergic neurons in the SNpc have degenerated and died [50]. In the same model, immune cells from the periphery were also recruited to the site of injury prior to neurodegeneration and MHCII expression was found at later time points in the striatum, as the inclusion pathology spread across the synapse from dopaminergic neurons in the SNpc to medium spiny neurons of the striatum [50]. Similarly, following a TBI in humans, activated microglia expand throughout the injured brain regions [114, 155]. In mice following a single controlled cortical impact, activated microglia and macrophages continue to express elevated levels of MHCII and CD68, a year after the injury [90].

Due to this similarity in immune response between PD and TBI, it is possible that TBI may accelerate underlying $\mathrm{PD}$ pathology in additive or synergistic manner thereby driving the subclinical PD pathology to overt PD 
pathology. Since both mice and rats exhibit similar immune responses as seen in human postmortem brain tissue, they are an adequate platform for further research that will help us understand how inflammation may drive TBI pathology toward development of PD.

\section{Metabolism}

The human brain consumes $20 \%$ of our calories but only accounts for $2 \%$ of the total body's mass [40, 128]. Most of this energy is used by neurons for saltatory signal transduction, while the rest is expended on housekeeping processes which include responses to injury [40]. Astrocytes, endothelial cells, pericytes and supplying blood vessels form a physiological neurovascular unit that provides the neuron with nutrients and also serves as a buffer for minor fluctuations in energy supply. Following a TBI, neurovascular unit damage results in disruption of homeostasis, excitotoxicity, production of reactive oxygen species, and inflammation $[44,66]$. Prolonged disruption of energy homeostasis, excitotoxicity, and damage from reactive oxygen species (ROS) promotes neuroinflammatory signaling cascade $[15,66,163]$. These events continue beyond the initial injury which may present an opportunity for therapeutic intervention, but may also create an environment conducive to nucleation of PD.

Nucleation of PD may be initially precipitated by decreased supply of metabolic nutrients and oxygen caused by damage to the blood brain barrier (BBB). Disruption of controlled and highly selective transport across the $\mathrm{BBB}$ results in a release of cytosolic and mitochondrial $\mathrm{Ca}^{2+}$, triggering intracellular catabolic processes accompanied by overproduction of ROS in neurons. Most of the neuronal ATP is produced through oxidative phosphorylation from densely packed neuronal mitochondria. Disruption of a delicate network of interconnected mitochondria undergoing near constant fusion and fission can result in inadequate energy production, decreased neuronal mitochondria membrane potential and increased production of ROS [64].

Intact mitochondrial membrane and functional electron transport chain complexes are essential for maintaining membrane potential between mitochondrial matrix and the cytosol [100]. This membrane potential is converted to usable energy by coupling of oxygen reduction to phosphorylation of ADP to ATP [100]. Damaged electron transport chain or compromised inner mitochondrial membrane resulting from TBI can cause increased ROS production along with decrease of ATP in neurons.

4-hydroxy-2-nonenal, a biproduct of membrane lipid peroxidation by ROS, can interact with soluble and highly abundant $\alpha$-syn protein and promote its aggregation into toxic oligomers in a dose dependent manner
$[4,122]$. Diverse lines of evidence show that $\alpha$-syn oligomers can interact with and disrupt mitochondrial function by impeding axonal transport of mitochondria [121], causing mitochondrial membrane destabilization and permeability $[47,160]$ and by interrupting electron transport chain machinery [91]. These are all components essential for ATP production. Inadequate energy production can exacerbate oligomerization of $\alpha$-syn by slowing down the energy-demanding autophagylysosomal and ubiquitin-proteasome degradation pathways. Both degradation pathways are involved in $\alpha$-syn turnover [161]. Over time, toxic oligomers could overwhelm the mitochondria's ability to maintain homeostasis, resulting in the death of energy demanding neurons like A9 dopaminergic neurons. As a last resort, degenerating neurons may sequester toxic $\alpha$-syn oligomers into the higher ordered cytosolic fibrils and Lewy bodies that are a hallmark of PD pathology.

Repeated brain injuries over the years may accelerate existing pathology resulting in earlier age of onset and increased severity within the late onset PD population. Perhaps repeated injuries in adulthood, may be more important at accelerating underlying PD pathology than those that occur in childhood, since younger brains recover more effectively than older brains after a TBI [97]. Additional support for the idea that TBI in adulthood may be more likely to nucleate or accelerate PD pathology comes from work by Uryu et al 2003. In their study, 24 month old mice that underwent controlled cortical impact TBI show more extensive, albeit transient conformational and nitrated $\alpha$-syn pathology compared to mice injured at 4 months [153].

\section{Protein aggregation}

Protein aggregation is a feature of many neurodegenerative diseases and is also a consequence of repeated head injury, as seen in the pathology of chronic traumatic encephalopathy (CTE) [104]. Further insight into the proteins most frequently found to aggregate both in PD and following TBI may shed light on as of yet elusive molecular connections.

$\alpha$-syn is an intrinsically disordered protein whose amyloidogenic properties and involvement in PD are well documented. $\alpha$-syn is made up of 140 amino acids encoded by the SNCA gene on chromosome 4q21q23 [22]. Under physiological conditions, most of the $\alpha$ syn in the brain is not phosphorylated, whereas in brains of patients with PD and other synucleinopathies Lewy bodies are almost exclusively made of $\alpha$-syn hyperphosphorylated at serine 129 residue [115]. $\alpha$-syn is highly abundant in neurons, and is concentrated in the nucleus and the synapse. While the precise biological function of $\alpha$-syn remains a mystery, its affinity toward certain phospholipid membranes and localization at the 
synapse has led to its implication in vesicular trafficking [7]. The exact molecular events that trigger the conversion of intrinsically disordered $\alpha$-syn into the pathologic oligomers and later sequestration into higher ordered structures seen in neurodegenerative diseases is also unclear. However, what is known is that $\alpha$-syn conversion into the pathogenic forms can be accelerated in vitro in a dose dependent manner with byproducts of free radical lipid peroxidation (e.g. 4-hydroxy-2-nonenal) and higher concentration of $\alpha$-syn $[4,154]$. Pesticides and heavy metal exposure has been linked to development of PD [126] and their addition in vitro has also been shown to accelerate oligomerization and aggregation of $\alpha$-syn [154]. In fact, fractioning fibrilized $\alpha$-syn by sonication into smaller fragments and injecting that material into the brains of rodents causes human like PD pathology [1]. This is a model of PD that at least in terms of $\alpha$-syn aggregate morphology most closely resembles pathology seen in idiopathic PD [157].

In vivo, the connection between PD pathogenesis and suspected risk factors is less clearly defined. $\alpha$-syn is elevated in the CSF of patients with TBI and also increases proportional to the severity of injury $[109,147]$. In these studies, adults and children with a Glasgow Coma Score $<8.0$ received a ventricular catheterization to allow for continuous drainage in an effort to alleviate intracranial pressure during which the CSF samples were collected. Patients without TBI that underwent a lumbar puncture for other medical reasons were used as controls. In both children and adults, higher levels of $\alpha$-syn in the CSF were associated with higher severity of injury $[109,147]$. In rodent controlled cortical impact-TBI models, $\alpha$-syn is elevated and is accompanied by neurodegeneration but without robust serine 129 positive Lewy body pathology that defines PD [2]. Following a TBI, elevated $\alpha-$ syn, increased ROS (promoting oligomerization), and compromised proteasomal function together may create an environment that promotes early PD pathology. From previous studies we know that free radical lipid peroxidation (e.g. 4-hydroxy-2-nonenal) and higher concentration of $\alpha$-syn can promote oligomerization into more toxic $\alpha$-syn aggregates $[4,154]$. It is therefore possible that higher concentration of $\alpha$-syn that accompanies TBI, together with damaged mitochondria which produce more ROS, may foster an environment conducive to PD pathology nucleation.

Amyloid beta $(\mathrm{A} \beta)$ is an approximately $4 \mathrm{kDa}, 36-43$ amino acid peptide, produced by cleavage of amyloid precursor protein (APP). The exact function of APP is not yet known but the production of APP and its processing is now well understood [112]. APP undergoes sequential proteolytic cleavage by two membrane bound endoproteases $\beta$ - and a $\gamma$-secretase. First, APP is cleaved by $\beta$-secretase releasing a large fragment $\operatorname{sAPP} \beta$. The remaining membrane bound 99 amino acid fragments are cleaved by $\gamma$-secretase generating $A \beta$. Along with Tau, which is discussed later in the text, $A \beta$ is most commonly associated with Alzheimer's disease (AD) when it aggregates into higher order parenchymal "senile plaques". While $A \beta$ plaques were thought to be the causative agent of neuronal degeneration in $\mathrm{AD}$, more recently oligomeric precursors have been shown to have even higher toxicity [137]. Like $\alpha$-syn, TDP-43, and Tau, misfolded $A \beta$ can "corrupt" soluble $A \beta$ and propagate aggregation in a prion-like fashion [136]. Unlike $\alpha$-syn, aggregation of $A \beta$ can be intracellular and extracellular, causing death of a variety of neurons in hippocampus, frontal cortex, and subcortical nuclei [138] . Studies show that $\mathrm{A} \beta$ toxicity can be receptor-mediated, occur by destabilizing plasma membranes, and by intracellular toxicity [70]. Extracellular $A \beta$ can interact with $\mathrm{N}$-methyl-D-aspartate receptor (NMDAR) leading to synaptic dysfunction followed by neurodegeneration leading to functional disruption [142]. Intercellular $A \beta$ is localized in mitochondrial membrane, endoplasmic reticulum, and lysosomal membranes where cytotoxicity is achieved by disruption of proper organelle function [70].

Levels of $A \beta$ fragment and senile plaques increases after a single TBI, when compared to age matched controls [65]. Postmortem brain tissue 1-47 years after a single TBI have $A \beta$ plaques throughout the brain while the plaques were exceedingly rare in age matched controls. These data suggest that just a single TBI event can predispose the brain to AD or PD later in life. In rodents even mild repetitive TBI has been shown to promote $A \beta$ pathology [38].

In a subpopulation of patients with Lewy body spectrum disorders, deposition of $\mathrm{A} \beta$ was found along with the Lewy bodies in dementia with Lewy bodies and to a lesser extent in PD dementia patients [37]. Over $80 \%$ of PD patients surviving more than a decade will eventually develop dementia, although the severity and onset can vary by years and sometimes decades [36]. In transgenic animals and in vitro, studies $A \beta$ was found to accelerate $\alpha$-syn aggregation into Lewy bodies and that $\alpha$-syn can in turn accelerate $A \beta$ aggregation $[25,28,77$, $99,117]$. Understanding the interaction between $\mathrm{AD}$ and PD pathology can help inform the search for treatments. Moreover, drugs found to be effective in human trials for $\mathrm{AD}$ [135] may be repurposed for treating PD, particularly at staving off dementia, since motor disturbances precede PD mental decline and dementia by years and sometimes decades.

TAR DNA-binding protein 43 (TDP-43) is most notably associated with amyotrophic lateral sclerosis (ALS), and over 50 mutations in the TARDP gene coding for TDP-43 have been found to cause ALS [111]. TDP-43 is normally located in the nucleus of most cells, and 
thousands of genes are transcriptionally regulated by TDP-43. In the pathology of neurodegenerative disorders including chronic traumatic encephalopathy (CTE) and frontotemporal lobar degeneration, TDP-43 positive inclusions are found in the cytoplasm $[6,105]$. TDP-43 positive inclusions also occur in patients with diagnosed PD and other neurodegenerative disorders with $\alpha$-syn pathology such as dementia with Lewy bodies [113]. TDP-43 is cleaved into 25 and $35 \mathrm{kDa}$ fragments, which are hyperphosphorylated, ubiquinated and aggregated into these inclusions. While limited clinical research exists on the relationship between chronic TBI and TDP43, behavioral symptoms normally associated with frontotemporal dementia (FTD) like apathy and social dysfunction also frequently occur in patients with TBI and CTE [150]. These symptoms are thought to occur as a result of frontal lobe degeneration.

Various animal models of TBI have been used extensively to interrogate TDP-43 proteinopathy [54]. Using either repetitive controlled cortical impact (CCI) or fluid percussion injury (FPI) TDP-43 fragments are found to be mislocalized to the cytoplasm where they are phosphorylated, causing neuronal death and impaired cognition in memory tests $[149,158,164]$. TDP-43 proteinopathy was also achieved in rodents using less severe repetitive closed head blast injury models. Exposure of anesthetized mice to 30 psi overpressure blast wave resulted in TDP43 proteinopathy, compared to controls which were only exposed to the blast sound and not the blast wave [166]. In a similar injury model, rats were exposed up to 4 repetitive mild blasts consisting of 13,16 , or 19 psi injuries delivered to the front or the side of the head resulting in TDP-43 proteinopathy [53]. Although TDP-43 positive inclusions occur in patients with $\alpha$-syn pathology, we found no evidence in literature of TDP-43 interaction or colocalization with Lewy bodies or Lewy neurites in humans. Future studies focused on determining chronic outcomes of TBIs that produced TDP-43 pathology in PD animal models with robust $\alpha$-syn pathology are necessary to determine how TDP-43 pathology fits in mechanistically with PD.

Tau is a highly soluble member of the microtubuleassociated protein (MAP) family, responsible for stabilizing microtubule assembly networks. Neuronal Tau include MAP-2A and MAP-4 $(>200 \mathrm{kDa})$, as well as a smaller MAP-2C ( > $80 \mathrm{kDa}$ ) [95]. Like $\alpha$-syn and $A \beta$, Tau has a well-established role in pathology of AD, PD and TBI. Of the two haplotypes $\mathrm{H} 1$ and $\mathrm{H} 2, \mathrm{H} 1$ has the strongest association with PD. The $\mathrm{H} 1$ haplotype, present in $87 \%$ of PD cases and $77 \%$ of controls is associated with increased risk for PD compared to the H2 haplotype [152]. Pathological presentation of Tau in neurodegenerative diseases like PD, and as seen in TBI, is in the form of neurofibrillary tangles (NFTs) resulting from Tau hyper phosphorylation. Hyperphosphorylation of Tau causes both loss of function leading to destabilization of the microtubule network and deposition of toxic aggregates, which can in turn affect structure and transport throughout the cell [79]. In idiopathic PD, Tau and $\alpha$-syn are colocalized in Lewy bodies [60]. Tau-positive Lewy bodies can be classified into four types based on immunoreactive Tau localization within the aggregates [60]. While widespread aggregation of $\alpha$ syn and Tau occurs in Lewy bodies in postmortem tissue from patients with various synucleiopathies (e.g. Dementia with Lewy bodies, Parkinson's disease, Frontotemporal dementia) the localization does not follow any particular Braak staging of disease severity [60]. Further evidence for a biological relationship between $\alpha$-syn and Tau is provided by in vitro and animal model studies.

In vitro protein interaction studies using bindings assays have shown that the $\mathrm{C}$-terminus of $\alpha$-syn domain binds reversibly to the microtubule binding domain of Tau and that this binding stimulates phosphorylation of Tau at serine residues 262 and 356 [63]. Transgenic mice harboring the rare familial A30P $\alpha$-syn mutation show increased Tau phosphorylation at serine residues 396 and 404 [42]. Western blot analysis demonstrates that immunoreactive Tau and $\alpha$-syn are significantly higher in A30P symptomatic mice than in A30P asymptomatic mice or age-matched non-transgenic littermate controls [42]. These studies together provide compelling evidence for a direct pathological relationship between Tau and $\alpha$-syn proteins in PD.

Tau has also been implicated in TBI pathology. Highprofile cases of athletes with CTE have garnered a great deal of media attention. CTE prevalence is still being elucidated along with additional details for diagnostic criteria [145]. CTE is a term used to describe brain degeneration that is likely caused by repetitive TBIs. As with most neurodegenerative disorders, confirmation is only possible postmortem, where Tau pathology is deposited within the cortical sulci around small blood vessels [46]. While TDP-43 is found in majority of CTE cases and amyloid beta pathology is found in 43\% of CTE cases, the presence of $\alpha$-syn pathology like Lewy bodies, is less clear [107]. Conclusive diagnosis of CTE is made more difficult because a significant portion of those diagnosed with CTE also present with pathology of other neurodegenerative diseases. Mckee et al. (2015) have shown that in 142 confirmed cases of CTE, 37 percent of patients shared comorbid pathology with one or more other neurodegenerative disorders including Alzheimer's Disease and Lewy body disease [107]. Other studies have shown that although Lewy Body pathology can occur in CTE, clinical presentation of Parkinsonism is not yet associated with CTE, and, to date, severity and 
frequency of injury necessary to cause Lewy body pathology is not known [3]. Future animal studies focused on Lewy Body pathology and TBI are warranted to provide much needed clarity on the severity and frequency of TBI necessary to cause CTE and/or PD related $\alpha$-syn pathology.

\section{Models of TBI and their application in PD research}

While no single animal model of TBI will ever recapitulate all features of human TBI, each of the models discussed below can answer specific questions about aspects of human TBI.

Certain mechanistic questions can be best addressed with primary or model neurons in culture. One such method involves growing neuronal cells on a silastic membrane that is then stretched using compressed gas mimicking torsional stress experience by neurons during TBI. This biaxial stretch injury model has been adopted for use in a variety of immortalized and primary cells and has led to a better understanding of primary astrocyte and immortalize neuron cell specific responses to injury $[39,68]$. In both studies, cell injury controllers were used to deliver a stretch injury to a monoculture of cells on a silastic membrane. The in vitro studies show that cellular responses are quantifiable and track with severity of injury in both astrocytes and immortalized neuronal cells.

To model TBI in vivo, several injury systems have been developed that cause skull penetrating and nonpenetrating injuries in cats, dogs, ferrets, mice, monkeys ,rats, and swine [165]. Rodent TBI models are the most extensively used and are summarized in (Table 1). It is important to note that most injury models involve preparatory surgeries (i.e. a craniotomy or skull exposure). Surgery prior to the intended TBI injury is an important consideration because it may prime the animal's immune system, thereby unintentionally enhancing the injury-specific inflammatory response. Modeling repetitive injuries, especially those separated by a significant time interval, may not be possible in TBI models that require surgeries. While repetitive closed head weight drop injuries that do not require preparatory surgeries have been well-documented in mice [133], they remain largely uncharacterized in rats. A modified Marmarou injury system developed by Buchele et al (2016) is a good candidate for further development into a repetitive TBI rat model without an incision. Additional consideration for modeling TBI in animals is the use of analgesia that is also anti-inflammatory. Aforementioned emerging evidence discussed above shows that inflammation in the form of infiltrating phagocytic cells from the periphery may help drive PD pathology. Therefore, the use of antiinflammatory analgesics during or after injury may confound the results of the study and how it may relate to PD pathology. Research specifically focused on determining a biological relationship between TBI and PD has not been extensive and warrants increased efforts.

\section{Blast TBI}

Exposure to a blast wave from detonation of friendly and enemy explosive ordinances is a signature injury of recent conflicts. Following a detonation, the surrounding air is displaced by rapidly expanding gases at high velocity. This rapid blast wave is followed by blast wind which can reach hurricane level forces and causes dismemberment and lacerations [59]. Therefore, a person

Table 1 Rodent TBI injury models. Controlled cortical impact (CCI), Fluid percussion injury (FPI), Penetrating ballistic brain injury $(\mathrm{PBBI})$, and closed head injury $(\mathrm{CHI})$ weight drop are the most commonly used injury methods

\begin{tabular}{llll}
\hline Model & Injury type & Preparatory surgery & Rodent \\
\hline Blast & Diffuse & None & Mouse [48], Rat [69] \\
CCI & Focal & Craniotomy & Mouse [141], Rat [35] \\
FPI & Mixed & Craniotomy & Rat [102] \\
Middle & Mixed & Craniotomy & Mouse [17], Rat [103] \\
Lateral & Diffuse & Craniotomy & Rat [34] \\
Repetitive & Focal & Cranial incision, burr hole & Rat [162] \\
PBBI & & & Rat [16] \\
Weight drop & Diffuse & Cranial incision & Mouse [133] \\
Buchele & Repetitive, diffuse & None & Rat [96] \\
Citron & Diffuse & Cranial incision, reflected periosteum & Rat [73] \\
Marmarou & Diffuse & Infraorbital incisions, temporary implant & Mouse [169] \\
Maryland model & Diffuse & None & Mouse [23], Rat [140] \\
Pick & Focal & Cranial incision & \\
Shohami & & &
\end{tabular}


exposed to an explosion suffers two injuries in rapid succession. Severity of exposure to the blast wave depends on the magnitude of the positive pressure wave where an overpressure of $414-552 \mathrm{kPa}$ or $60-80 \mathrm{psi}$ can be potentially lethal [59]. Another important consideration even at a distance from the explosion, is the reflection of a blast wave from nearby objects and buildings. A growing body of research exists on how blast injuries affect the brain and other organs in mice and rats, using blast tubes that are more reproducible and more readily accessible than explosive ordinance detonation [94]. However, only a handful of studies exist on how blast injuries affect the progression of Alzheimer's disease, and none exist on how blast injuries affect the progression of PD. Considering that blast injury is the signature type of TBI in recent conflicts and that Veterans with history of TBI are at a 56\% higher risk for developing PD [45], blast in the context of PD pathology deserves additional research efforts.

\section{Controlled cortical impact (CCI) TBI}

CCI consists of an impactor that delivers an injury to the exposed brain and has been extensively used in TBI research with over 2,600 publications to date. A typical CCI device is made up of an inert gas driven piston that directly impacts the brain resulting in controlled brain deformation. Using a pneumatic impactor, Dixon et al. (1995) performed injuries on anesthetized SD rats with 3 injury levels [35]. The CCI device was built at the Medical College of Virginia and was made up of a pneumatic cylinder with an adjustable impact velocity [35]. Dixon et al. performed acute and chronic neurological assessments and cardiovascular responses and also evaluated the histopathology of the injured animals. Acute neurological assessments consisted of non-postural somatosensory functions by recording duration of reflex suppression to noxious stimuli. Postural somatosensory function was evaluated by measuring duration of suppression of the righting reflex and escape. Chronic neurological deficits were measured by latency to cross a beam-balance. Cardiovascular response to injury was determined by measuring arterial blood pressure, and histopathology was evaluated by noting parenchymal bleeding and axonal swelling visualized using antibodies targeted at all three neurofilament subunits. In general, the evaluations tracked with severity of injury. Both acute and chronic evaluations exhibited graded response to the severity of injury with suppressed responses to noxious stimuli, increased beam balance time, and increased latency to cross. Animals that sustain low injury do not show damage beyond the immediate point of contact with the impactor, while moderate to high injury result in bilateral intraparenchymal bleeding. Staining with antibodies for neurofilament subunits shows axonal swelling characterized by "retraction balls" present throughout the brain. A similar study was performed in C57BL mice by Smith et al. (1995), showing approximately $50 \%$ memory deficits using the Morris Water Maze and extensive gliosis, indicated by staining for a glial fibrillary acidic protein (GFAP), a marker of astrocytes [141]. Foundational studies by Dixon and Smith have guided the TBI field for decades, as evidenced by over 1,500 citations.

CCI provides focal and highly reproducible injuries, resulting in improved animal studies. However, the open skull, cortical deforming nature of the injury is seldom seen in human TBIs. The major limitations of this model are that it requires a craniotomy and that even mild injuries result in observable cortical deformation. Moreover, this model does not lend itself to repetitive mild injuries which may drive the pathology of neurodegenerative diseases in humans. In PD studies there has been limited application of CCI, totaling in only three studies that evaluated functional and histological deficits closely associated with PD. Acosta et al. (2015) found that 60 days after a $\mathrm{CCI}$, there is an approximately $25 \%$ reduction in dopaminergic tyrosine hydroxylase-positive neurons in the ipsilateral SNpc and a two-fold increase in expression of $\alpha$-syn in the surviving neurons [2]. Loss of dopaminergic neurons in the SNpc was accompanied by an approximately 20-fold increase in the volume of MHCII expressing microglia, in the SNpc [2]. However, no phospho-Serine 129-positive Lewy body-like inclusion pathology was reported. Leucine rich repeat kinase 2 (LRRK2) is a well-established contributor to both late onset familial and idiopathic PD. Studies show that gain of function mutations in LRRK2 increase susceptibility to $\alpha$-syn pathology and that LRRK2 inhibition or knockout provides neuroprotection in multiple PD models [31, 86, 156]. More recently, LRRK2 expression was found to increase in CCI mouse TBI model, and LRRK2 inhibition was found to be neuroprotective [5]. Bae et al. (2018), show that inhibition of LRRK2 provides robust neuroprotection after a CCI in the cortex and hippocampus and that this neuroprotection results in improved motor function (beam balance) and memory (novel object recognition) tests.

Exposure to neurotoxins has been shown to cause PD later in life [126]. Exposure to neurotoxins may increase susceptibility to subsequent injuries like TBI that bring about clinical presentation of PD. Trichloroethylene (TCE), a halogenated hydrocarbon used as a solvent in the U.S., has been shown to cause PD-related functional deficits that are further exacerbated by TBI [131]. Using a CCI model, Sauerbeck et al. (2012) showed that exposure to either TCE or CCI alone does not result in dopaminergic neuron loss in the $\mathrm{SNpc}$, but exposure to both 
causes $13-17 \%$ loss, suggesting a synergistic relationship between TBI and TCE exposure [131]. They also show mitochondrial dysfunction in the striatum without the loss of dopaminergic innervation from the SNpc. Although these three studies indicate a strong relationship between TBI and PD, key mechanistic questions remain unanswered, such as the relationship between TBI and trans-synaptic spread of more authentic $\alpha$-syn Lewy body-like pathology consisting of dense perinuclear aggregates or corkscrew Lewy neurite-like structures as seen in human idiopathic PD [143]. Studies aimed at determining how focal injuries using $\mathrm{CCI}$ affect existing $\alpha$ syn pathology would greatly improve our knowledge on the dynamics and mechanisms between TBI to specific brain areas and development of PD related pathology.

\section{Fluid percussion injury (FPI)}

Fluid percussion Injuries continue to be used in animal studies since first described in 1966 by Lindgren and Rinder [87]. Original FPI devices caused percussive injury using a metal pendulum released from a predetermined height that struck a piston and drove saline into exposed intact dura. Contemporary FPI devices have computer-controlled pneumatic pistons that drive saline into the exposed dura, resulting in improved reproducibility [67]. Lateral [103], medial [102], and repetitive [34] injury models were developed in rats, and the parasagittal FPI injury model was also adapted to mice [17]. Only a few studies exist where FPI was used to study the effects of TBI on $\mathrm{AD}$ related pathology. In rats, 6 months after a lateral FPI AD related neuropathology is observed, including immunoreactivity to phosphorylated Tau and $\mathrm{A} \beta$, as well as gradual cortical neuronal loss [55]. In adult rats, FPI injury causes progressive loss of dopaminergic neurons and also enhances vulnerability to Paraquat, a pesticide linked to PD in humans [56]. In this study Paraquat and TBI was the only condition under which amorphous $\alpha$-syn intracellular aggregates developed suggesting a potential synergistic pathology [56]. Moreover, pioglitazone a drug prescribed to treat diabetes, has been shown to decrease levels of pro inflammatory cytokines, number of activated microglia around dopaminergic axons, and promote dopaminergic neuronal survival [88]. It would be of interest to determine the degree to which transsynaptic spread of $\alpha$-syn pathology is seen in FPI models that are also exposed to Paraquat. While the importance of FPI to our understanding of the biology that drives TBI pathology cannot be overstated, there are some limitations. FPI models are limited to same-day injuries and require a persistent craniectomy limiting our ability to study chronic effects of repetitive injuries on PD pathology.

\section{Penetrating ballistic brain injury (PBBI)}

Recent mass shootings in the U.S. have cast a public spotlight on gun-related injuries. In the U.S., 67,000 people are injured by ballistic firearms each year, making ballistic injury from firearms a major health concern [41]. Injuries to the head make up $10 \%$ of total gun related injuries [41] and only a third of these injuries are survived [11]. Still, thousands of individuals survive ballistic head trauma each year that predisposes them to neurodegenerative diseases later in life and warrants additional attention. The PBBI model, originally developed using mixed breed cats, consists of right frontal sinus removal thereby exposing the posterior sinus wall. A steel sphere is fired and penetrates the right frontal bone, passing through the entire length of the right cerebral hemisphere $[18,20]$. More recently, a PBBI model was developed in rats, and particular ballistic injury parameters were scaled from human to rat proportional to high-velocity North Atlantic Treaty Organization (NATO) round. A PBBI probe was inserted through the right frontal pole of the brain, and a balloon was inflated to $10 \%$ of total brain volume [162]. The probe delivered a survivable injury resulting in hemorrhage and necrosis in the nuclei that are also affected in PD (e.g., striatum and substantia nigra) as well as the cortex [162]. PBBI was not used in studies of AD or PD, but it would be of interest to the field to see how the most severe survivable brain injuries that occur in humans, affect susceptibility to development of PD pathology.

\section{Weight drop}

Weight drop injury models typically consist of a freefalling weight released from a predetermined height down a guide tube striking the animal's head (shielded or unshielded) or a temporary implant intended to focus the energy to a particular part of the skull. Weight drop models result in either diffuse axonal or focal injuries, the models can be further divided into Marmarou variants that allow for rotational acceleration and the Shoami model where the head of the animal is immobilized. The Marmarou model, developed in 1994, consists of a weight striking an anesthetized rat with a fixed stainless-steel disc preventing skull fracture [96]. The animal is placed on a sponge to allow for rotational acceleration. This model has been widely used to study TBI due to its ability to cause similar type of injury as seen in FPI without the need for a craniotomy. Several variants of the Marmarou model were created in both mice and rats. In the Maryland model, a Marmarou variant, force is applied to the frontal cranium through small metal implants. A temporary brass bar is implanted against the malar process on each side of the rat skull through an infraorbital incision, and these two bars are attached to a cylinder that is struck by a steel ball in 
free-roll down a ramp [73]. The injury causes anteriorposterior as well as sagittal rotational acceleration. Histological analysis of the brain tissue shows parenchymal bleeding, activated caspase- 3 and $\beta$-Amyloid precursor protein accumulation in the axons [73]. Another modified Marmarou rat model was developed by Buchele et al. (2016). In their model, the shielded head is struck at a 70-degree angle to accommodate electroencephalography/myography (EEG/EMG) electrodes in order to obtain electrophysiological recordings of vigilance states [16]. Limited space on the rat cranium prevented real time EEG/EMG recordings following a TBI so Buchele et al modified the Marmarou model by moving the impact target $2 \mathrm{~mm}$ anterior to bregma over the midline, allowing space on the calvarium for electrode implants. While they find no abnormalities between the sleep/wake cycle of injured and uninjured animals, Buchele et al. report memory deficits and microbleeds in the injured animals [16].

Using a similar setup scaled to mice, Zohar et al. developed a closed head mild TBI model that also does not require preparatory surgery. Anesthetized male ICR mice are placed under a vertical guide tube, through which a weight is dropped [169]. The mice are manually stabilized under the guide tube on a sponge so that temporal right side of the head between the eye and ear are targeted [169]. This closed head injury causes significant and irreversible learning impairments without causing damage to the skin, skull, or a compromised blood brain barrier. Advantages of this model are high survivability, ease of use, and, most importantly, the absence of preparatory surgeries. The same model developed by Zohar et al. (2003) was adopted by Saykally et al. to study how repetitive mild injuries alter protein expression and dendritic complexity in mice. The findings indicate that TDP-43 protein levels increase in the cortex ipsilateral to injury after day 3 and return to normal by 30 and 60 days post-injury, while the TDP-43 expression in the ipsilateral hippocampus increases only after 60 days [133]. They also reported a decrease in relative expression of autophagy factors and decreased dendritic arbor density.

Shohami mouse and rat injury models differ from Marmrou and other similar models in that the head is unshielded, the same impactor (with size-appropriate endpoints) is used for mice and rats, and the head is immobilized. The anesthetized animal is placed on a hard surface, skin is retracted exposing the skull, and the head is immobilized with 4 metal bars. The injury is delivered by a dropped weight [23]. The Shohami injury model produces more profound injuries whilst maintaining an intact skull, resulting in behavioral deficits and large cortical necrotic zones at the levels of hippocampus. While the intent of the Shohami injury device is to cause a focal injury, it is not difficult to imagine that the force of impact is distributed by the intact skull to other brain regions distal from the focal point of injury.

Several Alzheimer's disease/TBI studies were conducted using weight drop injury models, but only a single PD study has been conducted to date. Using a wellestablished 6-hydroxydopamine (6-OHDA) model of toxin induced PD together with a closed head weight drop model of injury, De Oliveira showed that a moderate TBI can increase vulnerability to neurotoxicity induced by 6-OHDA [33]. TBI + 6-OHDA caused impaired motor performance on a rotorod that was alleviated with $\mathrm{L}$-DOPA, compromised the $\mathrm{BBB}$, and decreased dopaminergic projections into the striatum [33]. However, in this study like other Parkinson's disease and TBI studies to date pathology reported lacked phosphoserine 129 positive, skein or corkscrew shaped Lewy neurite-like structures and dense Lewy body-like aggregates typical of human idiopathic PD.

\section{Future direction: Leucine Rich Repeat Kinase 2 (LRRK2) and Rab proteins}

Protein aggregation is a histological hallmark of both PD and TBI and understanding the upstream mechanisms that may bring about this aggregation and subsequent cell death merit further study. Recent focus has been on Leucine rich Repeat Kinas 2, due to its involvement in familial and idiopathic PD and do to its drugability.

The G2019S gain of function mutation in the LRRK2 protein, resulting in hyperactive kinase activity, is the most frequent genetic cause of late onset PD that is pathologically indistinguishable from idiopathic PD [29]. This increase in LRRK2 activity, however, is not found in idiopathic PD. LRRK2 is constitutively expressed in the brain, and the expression levels do not change with age or in idiopathic PD [168]. Furthermore, modest overexpression of LRRK2 alone in animal models has failed to cause selective loss of A9 neurons in the SNpc or produce robust $\alpha$-syn pathology [78, 84]. A recent hallmark study by Steger et al. (2016) identified a subset of Rab GTPase proteins as exclusive physiological substrates of Leucine-rich repeat kinase 2 (LRRK2) [144]. The study also shows that the hyperactive LRRK2 mutation shifts subcellular distribution of Rabs from cytosolic to membrane bound, which may adversely impact homeostatic Rab function [144]. Rab32, Rab11, Rab5, and Rab7 have been shown to operate in mitochondrial function, dopamine transport, and late endosomelysosome formation, respectively, all processes which are disrupted in PD. Furthermore, these and other Rabs have also been implicated in PD prior to identification of Rabs as physiological LRRK2 substrates. LRRK2 and Rab interactions may normally be controlled by spatial and temporal expression of Rabs that are disrupted by TBI. It is therefore possible that in the absence of PD- 
inducing LRRK2 mutations, TBI may play a major role. As the most common non-genetic risk factor for PD, mTBI may be responsible for increasing LRRK2 substrate availability by chronically elevating the expression levels of Rabs in the brain, causing selective loss of susceptible neurons. During an infection Rab proteins are rapidly mobilized in immune cells suggesting that they are responsive to external aversive stimuli [119]. What remains to be seen is if TBI increases expression of Rabs thereby providing abnormal substrates for LRRK2 in neurons and glial cells which may cause TBI induced PD.

\section{Conclusion}

TBI is a significant non-genetic risk factor for developing PD later in life. While TBI has been implicated in several neurodegenerative disorders the strongest emerging evidence is for a causative relationship with late onset PD. Accumulating evidence suggests that inflammation may play a significant role in PD pathogenesis following TBI, therefore animal models that do not require preparatory surgeries should be considered to avoid confounding results of injury. According to current literature, there is a significant pathological overlap between late onset PD and TBI including protein aggregation, but the area of research in animal models remains under-explored with only a few animal studies focusing on specific aspects of PD pathology using TBI models. Better understanding of the mechanisms prior to the onset of neurodegeneration, like the interactions between LRRK2 and Rabs may uncover targets amenable to pharmacological intervention which could lead to preventative treatments for PD following a TBI.

\section{Acknowledgements}

We would also like to thank Kathleen E. Murray for useful discussion.

\begin{abstract}
Authors' contributions
Vedad Delic conceived of the review and wrote the manuscript. Vedad Delic also provided Parkinson's disease and neurodegenerative expertise. Kevin Beck, Kevin Pang, and Bruce Citron have extensive experience with animal models of TBI. They have provided guidance and TBI expertise in writing and reviewing this manuscript. The author(s) read and approved the final manuscript.

Funding

This work was supported by the Department of Veterans Affairs (Veterans Health Administration, Office of Research and Development, Rehabilitation Research and Development (101RX001520) and Biomedical Laboratory Research and Development (I21BX003815, 101BX000132), the Assistant Secretary of Defense for Health Affairs through the Congressionally Directed Gulf War Illness Research Program (W81XWH-16-1-0626), and the Veterans Bio-Medical Research Institute.
\end{abstract}

\section{Availability of data and materials} NA

\section{Consent for publication}

We have the consent of the authors for publication

\section{Competing interests}

No competing financial interests exist. The contents do not represent the views of the Department of Veterans Affairs or the United States Government and the opinions, interpretations, conclusions and recommendations are those of the authors and are not necessarily endorsed by the Department of Defense.

\section{Author details}

'Laboratory of Molecular Biology, VA New Jersey Health Care System, Research and Development (Mailstop 15), 385 Tremont Ave, East Orange, NJ 07018, USA. ${ }^{2}$ NeuroBehavioral Research Laboratory, VA New Jersey Health Care System, Research and Development (Mailstop 15), 385 Tremont Ave, East Orange, NJ 07018, USA. ${ }^{3}$ Department of Pharmacology, Physiology, and Neuroscience, Rutgers- New Jersey Medical School, Newark, NJ 07103, USA.

Received: 18 February 2020 Accepted: 26 March 2020

Published online: 07 April 2020

\section{References}

1. Abdelmotilib H, Maltbie T, Delic V, Liu Z, Hu X, Fraser KB, Moehle MS, Stoyka L, Anabtawi N, Krendelchtchikova V et al (2017) alpha-Synuclein fibrilinduced inclusion spread in rats and mice correlates with dopaminergic Neurodegeneration. Neurobiol Dis 105:84-98. https://doi.org/10.1016/..nbd. 2017.05.014

2. Acosta SA, Tajiri N, de la Pena I, Bastawrous M, Sanberg PR, Kaneko Y, Borlongan CV (2015) Alpha-synuclein as a pathological link between chronic traumatic brain injury and Parkinson's disease. J Cell Physiol 230:1024-1032. https://doi.org/10.1002/jcp.24830

3. Adams JW, Alvarez VE, Mez J, Huber BR, Tripodis Y, Xia W, Meng G, Kubilus CA, Cormier K, Kiernan PTet al (2018) Lewy Body Pathology and Chronic Traumatic Encephalopathy Associated With Contact Sports. J Neuropathol Exp Neurol 77: 757-768 Doi https://doi.org/10.1093/jnen/nly065

4. Bae EJ, Ho DH, Park E, Jung JW, Cho K, Hong JH, Lee HJ, Kim KP, Lee SJ (2013) Lipid peroxidation product 4-hydroxy-2-nonenal promotes seedingcapable oligomer formation and cell-to-cell transfer of alpha-synuclein. Antioxid Redox Signal 18:770-783. https://doi.org/10.1089/ars.2011.4429

5. Bae YH, Joo H, Bae J, Hyeon SJ, Her S, Ko E, Choi HG, Ryu H, Hur EM, Bu Yet al (2018) Brain injury induces HIF-1alpha-dependent transcriptional activation of LRRK2 that exacerbates brain damage. Cell Death Dis 9: 1125 Doi https://doi.org/10.1038/s41419-018-1180-y

6. Baralle M, Buratti E, Baralle FE (2013) The role of TDP-43 in the pathogenesis of ALS and FTLD. Biochem Soc T 41:1536-1540. https://doi.org/10.1042/ Bst20130186

7. Bendor JT, Logan TP, Edwards RH (2013) The function of alpha-synuclein. Neuron 79:1044-1066. https://doi.org/10.1016/..neuron.2013.09.004

8. Bennett DA, Schneider JA, Arvanitakis Z, Wilson RS (2012) Overview and findings from the religious orders study. Curr Alzheimer Res 9:628-645. https://doi.org/10.2174/156720512801322573

9. Bennett DA, Schneider JA, Buchman AS, Barnes LL, Boyle PA, Wilson RS (2012) Overview and findings from the rush Memory and Aging Project. Curr Alzheimer Res 9:646-663. https://doi.org/10.2174/156720512801322663

10. Bjornestad A, Forsaa EB, Pedersen KF, Tysnes OB, Larsen JP, Alves G (2016) Risk and course of motor complications in a population-based incident Parkinson's disease cohort. Parkinsonism Relat Disord 22:48-53. https://doi. org/10.1016/j.parkreldis.2015.11.007

11. Blissitt PA (2006) Care of the critically ill patient with penetrating head injury. Crit Care Nurs Clin North Am 18:321-332. https://doi.org/10.1016/j. ccell.2006.05.006

12. Bloch A, Probst A, Bissig H, Adams H, Tolnay M (2006) alpha-Synuclein pathology of the spinal and peripheral autonomic nervous system in neurologically unimpaired elderly subjects. Neuropathol Appl Neurobiol 32: 284-295. https://doi.org/10.1111/j.1365-2990.2006.00727.x

13. Braak H, Del Tredici K, Rub U, de Vos RAl, Steur ENHJ, Braak E (2003) Staging of brain pathology related to sporadic Parkinson's disease. Neurobiology of Aging 24: 197-211 Doi Pii S0197-4580(02)00065-9. https://doi.org/10.1016/ S0197-4580(02)00065-9

14. Braak H, Rub U, Gai WP, Del Tredici K (2003) Idiopathic Parkinson's disease: possible routes by which vulnerable neuronal types may be subject to 
neuroinvasion by an unknown pathogen. J Neural Transm 110:517-536. https://doi.org/10.1007/s00702-002-0808-2

15. Brough D, Tyrrell PJ, Allan SM (2011) Regulation of interleukin-1 in acute brain injury. Trends Pharmacol Sci 32:617-622. https://doi.org/10.1016/j.tips. 2011.06.002

16. Buchele F, Morawska MM, Schreglmann SR, Penner M, Muser M, Baumann CR, Noain D (2016) Novel Rat Model of Weight Drop-Induced Closed Diffuse Traumatic Brain Injury Compatible with Electrophysiological Recordings of Vigilance States. J Neurotrauma 33:1171-1180. https://doi.org/10.1089/neu. 2015.4001

17. Carbonell WS, Maris DO, McCall T, Grady MS (1998) Adaptation of the fluid percussion injury model to the mouse. J Neurotrauma 15:217-229. https:// doi.org/10.1089/neu.1998.15.217

18. Carey ME (1995) Experimental missile wounding of the brain. Neurosurg Clin N Am 6:629-642

19. Cereda E, Barichella M, Cassani E, Caccialanza R, Pezzoli G (2013) Reproductive factors and clinical features of Parkinson's disease. Parkinsonism Relat Disord 19:1094-1099. https://doi.org/10.1016/j.parkreldis.2013.07.020

20. Cernak I (2005) Animal models of head trauma. NeuroRx 2:410-422. https:// doi.org/10.1602/neurorx.2.3.410

21. Chartier-Harlin MC, Kachergus J, Roumier C, Mouroux V, Douay X, Lincoln S, Levecque C, Larvor L, Andrieux J, Hulihan Met al (2004) Alpha-synuclein locus duplication as a cause of familial Parkinson's disease. Lancet 364: 1167-1169 Doi https://doi.org/10.1016/S0140-6736(04)17103-1

22. Chen X, de Silva HA, Pettenati MJ, Rao PN, St George-Hyslop P, Roses AD, Xia Y, Horsburgh K, Ueda K, Saitoh T (1995) The human NACP/alphasynuclein gene: chromosome assignment to 4q21.3-q22 and Taql RFLP analysis. Genomics 26:425-427

23. Chen Y, Constantini S, Trembovler V, Weinstock M, Shohami E (1996) An experimental model of closed head injury in mice: pathophysiology, histopathology, and cognitive deficits. J Neurotrauma 13:557-568. https:// doi.org/10.1089/neu.1996.13.557

24. Chung CY, Seo H, Sonntag KC, Brooks A, Lin L, Isacson O (2005) Cell typespecific gene expression of midbrain dopaminergic neurons reveals molecules involved in their vulnerability and protection. Hum Mol Genet 14: 1709-1725. https://doi.org/10.1093/hmg/ddi178

25. Clinton LK, Blurton-Jones M, Myczek K, Trojanowski JQ, LaFerla FM (2010) Synergistic Interactions between A beta, Tau, and alpha-Synuclein: Acceleration of Neuropathology and Cognitive Decline. J Neurosci 30:72817289. https://doi.org/10.1523/Jneurosci.0490-10.2010

26. Colombo D, Abbruzzese G, Antonini A, Barone P, Bellia G, Franconi F, Simoni L, Attar M, Zagni E, Haggiag Set al (2015) The "gender factor" in wearing-off among patients with Parkinson's disease: a post hoc analysis of DEEP study. ScientificWorldJournal 2015: 787451 Doi https://doi.org/10. 1155/2015/787451

27. Comi C, Magistrelli L, Oggioni GD, Carecchio M, Fleetwood T, Cantello R, Mancini F, Antonini A (2014) Peripheral nervous system involvement in Parkinson's disease: Evidence and controversies. Parkinsonism Relat D 20: 1329-1334. https://doi.org/10.1016/j.parkreldis.2014.10.010

28. Compta Y, Parkkinen L, Kempster P, Selikhova M, Lashley T, Holton JL, Lees AJ, Revesz T (2014) The Significance of alpha-Synuclein, Amyloid-beta and Tau Pathologies in Parkinsn's Disease Progression and Related Dementia. Neurodegener Dis 13:154-156. https://doi.org/10.1159/000354670

29. Cookson MR (2015) LRRK2 Pathways Leading to Neurodegeneration. Curr Neurol Neurosci Rep 15:42. https://doi.org/10.1007/s11910-015-0564-y

30. Crane PK, Gibbons LE, Dams-O'Connor K, Trittschuh E, Leverenz JB, Keene CD, Sonnen J, Montine TJ, Bennett DA, Leurgans Set al (2016) Association of Traumatic Brain Injury With Late-Life Neurodegenerative Conditions and Neuropathologic Findings. JAMA Neurol 73: 1062-1069 Doi https://doi.org/ 10.1001/jamaneurol.2016.1948

31. Daher JP, Volpicelli-Daley LA, Blackburn JP, Moehle MS, West AB (2014) Abrogation of alpha-synuclein-mediated dopaminergic neurodegeneration in LRRK2-deficient rats. Proc Natl Acad Sci U S A 111:9289-9294. https://doi. org/10.1073/pnas.1403215111

32. Davie CA (2008) A review of Parkinson's disease. Br Med Bull 86:109-127. https://doi.org/10.1093/bmb/ldn013

33. de Oliveira PA, Ben J, Matheus FC, Schwarzbold ML, Moreira ELG, Rial D, Walz R, Prediger RD (2017) Moderate traumatic brain injury increases the vulnerability to neurotoxicity induced by systemic administration of 6hydroxydopamine in mice. Brain Res 1663:78-86. https://doi.org/10.1016/j. brainres.2017.03.002
34. DeRoss AL, Adams JE, Vane DW, Russell SJ, Terella AM, Wald SL (2002) Multiple head injuries in rats: effects on behavior. J Trauma 52:708-714

35. Dixon CE, Clifton GL, Lighthall JW, Yaghmai AA, Hayes RL (1991) A controlled cortical impact model of traumatic brain injury in the rat. J Neurosci Methods 39:253-262

36. Edison P, Ahmed I, Fan Z, Hinz R, Gelosa G, Chaudhuri KR, Walker Z, Turkheimer FE, Brooks DJ (2013) Microglia, Amyloid, and Glucose Metabolism in Parkinson's Disease with and without Dementia. Neuropsychopharmacol 38:938-949. https://doi.org/10.1038/npp.2012.255

37. Edison P, Rowe CC, Rinne JO, Ng S, Ahmed I, Kemppainen N, Villemagne VL, O'Keefe G, Nagren K, Chaudhury KR et al (2008) Amyloid load in Parkinson's disease dementia and Lewy body dementia measured with [11C]PIB positron emission tomography. J Neurol Neurosur Ps 79:1331-1338. https:// doi.org/10.1136/jnnp.2007.127878

38. Edwards G, Moreno-Gonzalez I, Soto C (2017) Amyloid-beta and tau pathology following repetitive mild traumatic brain injury. Biochem Bioph Res Co 483:1137-1142. https://doi.org/10.1016/j.bbrc.2016.07.123

39. Ellis EF, McKinney JS, Willoughby KA, Liang S, Povlishock JT (1995) A new model for rapid stretch-induced injury of cells in culture: characterization of the model using astrocytes. J Neurotrauma 12:325-339. https://doi.org/10. 1089/neu.1995.12.325

40. Engl E, Attwell D (2015) Non-signalling energy use in the brain. J Physiol 593:3417-3429. https://doi.org/10.1113/jphysiol.2014.282517

41. Fowler KA, Dahlberg LL, Haileyesus T, Annest JL (2015) Firearm injuries in the United States. Prev Med 79:5-14. https://doi.org/10.1016/.ypmed.2015.06.002

42. Frasier M, Walzer M, McCarthy L, Magnuson D, Lee JM, Haas C, Kahle P, Wolozin B (2005) Tau phosphorylation increases in symptomatic mice overexpressing A30P alpha-synuclein. Exp Neurol 192:274-287. https://doi. org/10.1016/j.expneurol.2004.07.016

43. Fujiwara H, Hasegawa M, Dohmae N, Kawashima A, Masliah E, Goldberg MS, Shen J, Takio K, Iwatsubo T (2002) alpha-Synuclein is phosphorylated in synucleinopathy lesions. Nat Cell Biol 4:160-164. https://doi.org/10.1038/ ncb748

44. Gaetz M (2004) The neurophysiology of brain injury. Clin Neurophysiol 115: 4-18

45. Gardner RC, Byers AL, Barnes DE, Li Y, Boscardin J, Yaffe K (2018) Mild TBI and risk of Parkinson disease: A Chronic Effects of Neurotrauma Consortium Study. Neurology 90:e1771-e1779. https://doi.org/10.1212/WNL. 0000000000005522

46. Geddes JF, Vowles GH, Nicoll JA, Revesz T (1999) Neuronal cytoskeletal changes are an early consequence of repetitive head injury. Acta Neuropathol 98:171-178. https://doi.org/10.1007/s004010051066

47. Ghio S, Camilleri A, Caruana M, Ruf VC, Schmidt F, Leonov A, Ryazanov S, Griesinger C, Cauchi RJ, Kamp F et al (2019) Cardiolipin Promotes PoreForming Activity of Alpha-Synuclein Oligomers in Mitochondrial Membranes. ACS Chem Neurosci 10:3815-3829. https://doi.org/10.1021/ acschemneuro. $9 \mathrm{~b} 00320$

48. Goldstein LE, Fisher AM, Tagge CA, Zhang XL, Velisek L, Sullivan JA, Upreti C, Kracht JM, Ericsson M, Wojnarowicz MW et al (2012) Chronic traumatic encephalopathy in blast-exposed military veterans and a blast neurotrauma mouse model. Sci Transl Med 4(134):ra160. https://doi.org/10.1126/ scitranslmed. 3003716

49. Haaxma CA, Bloem BR, Borm GF, Oyen WJ, Leenders KL, Eshuis S, Booij J, Dluzen DE, Horstink MW (2007) Gender differences in Parkinson's disease. J Neurol Neurosurg Psychiatry 78:819-824. https://doi.org/10. 1136/jnnp.2006.103788

50. Harms AS, Delic V, Thome AD, Bryant N, Liu Z, Chandra S, Jurkuvenaite A, West AB (2017) alpha-Synuclein fibrils recruit peripheral immune cells in the rat brain prior to neurodegeneration. Acta Neuropathol Commun 5: 85. https://doi.org/10.1186/s40478-017-0494-9

51. Hawkes CH, Del Tredici K, Braak H (2009) Parkinson's Disease The Dual Hit Theory Revisited. Ann N Y Acad Sci 1170:615-622. https://doi.org/10.1111/j. 1749-6632.2009.04365.x

52. Hawkes CH, Del Tredici K, Braak H (2007) Parkinson's disease: a dual-hit hypothesis. Neuropathol Appl Neurobiol 33:599-614. https://doi.org/10. 1111/j.1365-2990.2007.00874.x

53. Heyburn L, Abutarboush R, Goodrich S, Urioste R, Batuure A, Statz J, Wilder D, Ahlers ST, Long JB, Sajja VSSS (2019) Repeated Low-Level Blast Overpressure Leads to Endovascular Disruption and Alterations in TDP-43 and Piezo2 in a Rat Model of Blast TBI. Front Neurol 10: Doi ARTN 766. https://doi.org/10.3389/fneur.2019.00766 
54. Heyburn L, Sajja VSSS, Long JB (2019) The Role of TDP-43 in MilitaryRelevant TBI and Chronic Neurodegeneration. Front Neurol 10: Doi ARTN 680. https://doi.org/10.3389/fneur.2019.00680

55. Hoshino S, Tamaoka A, Takahashi M, Kobayashi S, Furukawa T, Oaki Y, Mori O, Matsuno S, Shoji S, Inomata Met al (1998) Emergence of immunoreactivities for phosphorylated tau and amyloid-beta protein in chronic stage of fluid percussion injury in rat brain. Neuroreport 9: 18791883 Doi https://doi.org/10.1097/00001756-199806010-00039

56. Hutson CB, Lazo CR, Mortazavi F, Giza CC, Hovda D, Chesselet MF (2011) Traumatic brain injury in adult rats causes progressive nigrostriatal dopaminergic cell loss and enhanced vulnerability to the pesticide paraquat. J Neurotrauma 28:1783-1801. https://doi.org/10.1089/neu.2010.1723

57. Ibáñez $P$, Bonnet AM, Débarges B, Lohmann E, Tison F, Agid Y, Dürr A, Brice A, Pollak $P$ Causal relation between a-synuclein locus duplication as a cause of familial Parkinson's disease. Lancet 364:1169-1171. https://doi.org/10. 1016/S0140-6736(04)17104-3

58. Imamura K, Hishikawa N, Sawada M, Nagatsu T, Yoshida M, Hashizume Y (2003) Distribution of major histocompatibility complex class II-positive microglia and cytokine profile of Parkinson's disease brains. Acta Neuropathol 106:518-526. https://doi.org/10.1007/s00401-003-0766-2

59. Institute of M (2014) Gulf War and Health: Volume 9: Long-Term Effects of Blast Exposures. The National Academies Press, City

60. Ishizawa T, Mattila P, Davies P, Wang DS, Dickson DW (2003) Colocalization of tau and alpha-synuclein epitopes in Lewy bodies. J Neuropathol Exp Neurol 62:389-397. https://doi.org/10.1093/jnen/62.4.389

61. Jafari S, Etminan M, Aminzadeh F, Samii A (2013) Head injury and risk of Parkinson disease: a systematic review and meta-analysis. Mov Disord 28 1222-1229. https://doi.org/10.1002/mds.25458

62. Jellinger KA (2004) Lewy body-related alpha-synucleinopathy in the aged human brain. J Neural Transm 111:1219-1235. https://doi.org/10.1007/ s00702-004-0138-7

63. Jensen PH, Hager H, Nielsen MS, Hojrup P, Gliemann J, Jakes R (1999) Alphasynuclein binds to tau and stimulates the protein kinase A-catalyzed tau phosphorylation of serine residues 262 and 356. J Biol Chem 274:2548125489. https://doi.org/10.1074/jbc.274.36.25481

64. Jezek J, Cooper KF, Strich R (2018) Reactive Oxygen Species and Mitochondrial Dynamics: The Yin and Yang of Mitochondrial Dysfunction and Cancer Progression. Antioxidants Basel 7: Doi ARTN 13. https://doi.org/ 10.3390/antiox7010013

65. Johnson VE, Stewart W, Smith DH (2012) Widespread Tau and Amyloid-Beta Pathology Many Years After a Single Traumatic Brain Injury in Humans. Brain Pathol 22:142-149. https://doi.org/10.1111/j.1750-3639.2011.00513.x

66. Jullienne A, Badaut J (2013) Molecular contributions to neurovascular unit dysfunctions after brain injuries: lessons for target-specific drug development. Future Neurol 8:677-689. https://doi.org/10.2217/fnl.13.55

67. Kabadi SV, Hilton GD, Stoica BA, Zapple DN, Faden Al (2010) Fluidpercussion-induced traumatic brain injury model in rats. Nat Protoc 5:15521563. https://doi.org/10.1038/nprot.2010.112

68. Kane MJ, Hatic H, Delic V, Dennis JS, Butler CL, Saykally JN, Citron BA (2011) Modeling the pathobiology of repetitive traumatic brain injury in immortalized neuronal cell lines. Brain Res 1425:123-131. https://doi.org/10. 1016/j.brainres.2011.09.047

69. Kaur C, Singh J, Lim MK, Ng BL, Yap EP, Ling EA (1995) The response of neurons and microglia to blast injury in the rat brain. Neuropathol Appl Neurobiol 21:369-377

70. Kayed R, Lasagna-Reeves CA (2013) Molecular mechanisms of amyloid oligomers toxicity. J Alzheimers Dis 33(Suppl 1):S67-S78. https://doi.org/10. 3233/JAD-2012-129001

71. Khoo TK, Yarnall AJ, Duncan GW, Coleman S, O'Brien JT, Brooks DJ, Barker RA, Burn DJ (2013) The spectrum of nonmotor symptoms in early Parkinson disease. Neurology 80:276-281. https://doi.org/10.1212/WNL. 0b013e31827deb74

72. Kiely AP, Asi YT, Kara E, Limousin P, Ling H, Lewis P, Proukakis C, Quinn N, Lees AJ, Hardy J et al (2013) alpha-Synucleinopathy associated with G51D SNCA mutation: a link between Parkinson's disease and multiple system atrophy? Acta Neuropathol 125:753-769. https://doi.org/10.1007/s00401013-1096-7

73. Kilbourne M, Kuehn R, Tosun C, Caridi J, Keledjian K, Bochicchio G, Scalea T, Gerzanich V, Simard JM (2009) Novel model of frontal impact closed head injury in the rat. J Neurotrauma 26:2233-2243. https://doi.org/10.1089/neu. 2009.0968
74. Kitada T, Asakawa S, Hattori N, Matsumine H, Yamamura Y, Minoshima S, Yokochi M, Mizuno Y, Shimizu N (1998) Mutations in the parkin gene cause autosomal recessive juvenile parkinsonism. Nature 392:605-608. https://doi. org/10.1038/33416

75. Kruger R, Kuhn W, Muller T, Woitalla D, Graeber M, Kosel S, Przuntek H, Epplen JT, Schols L, Riess O (1998) Ala30Pro mutation in the gene encoding alpha-synuclein in Parkinson's disease. Nat Genet 18:106-108. https://doi. org/10.1038/ng0298-106

76. Kukull WA, Higdon R, Bowen JD, McCormick WC, Teri L, Schellenberg GD, van Belle G, Jolley L, Larson EB (2002) Dementia and Alzheimer disease incidence: a prospective cohort study. Arch Neurol 59:1737-1746. https:// doi.org/10.1001/archneur.59.11.1737

77. Lashley T, Holton JL, Gray E, Kirkham K, O'Sullivan SS, Hilbig A, Wood NW, Lees AJ, Revesz T (2008) Cortical alpha-synuclein load is associated with amyloid-beta plaque burden in a subset of Parkinson's disease patients. Acta Neuropathol 115:417-425. https://doi.org/10.1007/s00401-007-0336-0

78. Lee JW, Tapias V, Di Maio R, Greenamyre JT, Cannon JR (2015) Behavioral, neurochemical, and pathologic alterations in bacterial artificial chromosome transgenic G2019S leucine-rich repeated kinase 2 rats. Neurobiol Aging 36: 505-518. https://doi.org/10.1016/j.neurobiolaging.2014.07.011

79. Lee VMY, Goedert M, Trojanowski JQ (2001) Neurodegenerative tauopathies. Annu Rev Neurosci 24:1121-1159. https://doi.org/10.1146/annurev.neuro.24. 1.1121

80. Leentjens AFG, Dujardin K, Marsh L, Martinez-Martin P, Richard IH, Starkstein SE (2011) Symptomatology and Markers of Anxiety Disorders in Parkinson's Disease: A Cross-Sectional Study. Mov Disord 26:484-492. https://doi.org/10. 1002/mds.23528

81. Lenka A, Pagonabarraga J, Pal PK, Bejr-Kasem H, Kulisvesky J (2019) Minor hallucinations in Parkinson disease: A subtle symptom with major clinical implications. Neurology 93:259-266. https://doi.org/10.1212/WNL. 0000000000007913

82. Lesage S, Anheim M, Letournel F, Bousset L, Honore A, Rozas N, Pieri L, Madiona K, Durr A, Melki Ret al (2013) G51D alpha-synuclein mutation causes a novel parkinsonian-pyramidal syndrome. Ann Neurol 73: 459-471 Doi https://doi.org/10.1002/ana.23894

83. Li JY, Englund E, Holton JL, Soulet D, Hagell P, Lees AJ, Lashley T, Quinn NP, Rehncrona S, Bjorklund Aet al (2008) Lewy bodies in grafted neurons in subjects with Parkinson's disease suggest host-to-graft disease propagation. Nat Med 14: 501-503 Doi https://doi.org/10.1038/nm1746

84. Li X, Patel JC, Wang J, Avshalumov MV, Nicholson C, Buxbaum JD, Elder GA Rice ME, Yue Z (2010) Enhanced striatal dopamine transmission and motor performance with LRRK2 overexpression in mice is eliminated by familial Parkinson's disease mutation G2019S. J Neurosci 30:1788-1797. https://doi. org/10.1523/JNEUROSCI.5604-09.2010

85. Lill CM (2016) Genetics of Parkinson's disease. Mol Cell Probes 30:386-396. https://doi.org/10.1016/j.mcp.2016.11.001

86. Lin X, Parisiadou L, Gu XL, Wang L, Shim H, Sun L, Xie C, Long CX, Yang WJ, Ding Jet al (2009) Leucine-rich repeat kinase 2 regulates the progression of neuropathology induced by Parkinson's-disease-related mutant alphasynuclein. Neuron 64: 807-827 Doi https://doi.org/10.1016/j.neuron.2009.11.006

87. Lindgren S, Rinder L (1966) Experimental studies in head injury. II. Pressure propagation in "percussion concussion". Biophysik 3:174-180. https://doi. org/10.1007/bf01191611

88. Liu M, Bachstetter AD, Cass WA, Lifshitz J, Bing G (2017) Pioglitazone Attenuates Neuroinflammation and Promotes Dopaminergic Neuronal Survival in the Nigrostriatal System of Rats after Diffuse Brain Injury. J Neurotrauma 34:414-422. https://doi.org/10.1089/neu.2015.4361

89. Lizhnyak PN, Ottens AK (2015) Proteomics: in pursuit of effective traumatic brain injury therapeutics. Expert Rev Proteomics 12:75-82. https://doi.org/10. 1586/14789450.2015.1000869

90. Loane DJ, Kumar A, Stoica BA, Cabatbat R, Faden Al (2014) Progressive neurodegeneration after experimental brain trauma: association with chronic microglial activation. J Neuropathol Exp Neurol 73:14-29. https:// doi.org/10.1097/NEN.0000000000000021

91. Ludtmann MHR, Angelova PR, Horrocks MH, Choi ML, Rodrigues M, Baev AY, Berezhnov AV, Yao Z, Little D, Banushi Bet al (2018) alpha-synuclein oligomers interact with ATP synthase and open the permeability transition pore in Parkinson's disease. Nat Commun 9: 2293 Doi https://doi.org/10. 1038/s41467-018-04422-2

92. Luk KC, Kehm V, Carroll J, Zhang B, O'Brien P, Trojanowski JQ, Lee VM (2012) Pathological alpha-synuclein transmission initiates Parkinson-like 
neurodegeneration in nontransgenic mice. Science 338:949-953. https://doi. org/10.1126/science.1227157

93. Ma JN, Gao J, Wang J, Xie AM (2019) Prion-Like Mechanisms in Parkinson's Disease. Front Neurosci-Switz 13: Doi ARTN 552. https://doi.org/10.3389/ fnins.2019.00552

94. Ma X, Aravind A, Pfister BJ, Chandra N, Haorah J (2019) Animal Models of Traumatic Brain Injury and Assessment of Injury Severity. Mol Neurobiol 56: 5332-5345. https://doi.org/10.1007/s12035-018-1454-5

95. Maccioni RB, Cambiazo V (1995) Role of Microtubule-Associated Proteins in the Control of Microtubule Assembly. Physiol Rev 75:835-864

96. Marmarou A, Foda MA, van den Brink W, Campbell J, Kita H, Demetriadou K (1994) A new model of diffuse brain injury in rats. Part I: Pathophysiology and biomechanics. J Neurosurg 80:291-300. https://doi.org/10.3171/jns.1994. 80.2.0291

97. Marquez de la Plata CD, Hart T, Hammond FM, Frol AB, Hudak A, Harper CR O'Neil-Pirozzi TM, Whyte J, Carlile M, Diaz-Arrastia R (2008) Impact of age on long-term recovery from traumatic brain injury. Arch Phys Med Rehabil 89: 896-903. https://doi.org/10.1016/j.apmr.2007.12.030

98. Marras C, Beck JC, Bower JH, Roberts E, Ritz B, Ross GW, Abbott RD, Savica R, Van Den Eeden SK, Willis AW et al (2018) Prevalence of Parkinson's disease across North America. NPJ Parkinsons Dis 4:21. https://doi.org/10.1038/ s41531-018-0058-0

99. Masliah E, Rockenstein E, Veinbergs I, Sagara Y, Mallory M, Hashimoto M, Mucke L (2001) beta-Amyloid peptides enhance alpha-synuclein accumulation and neuronal deficits in a transgenic mouse model linking Alzheimer's disease and Parkinson's disease. P Natl Acad Sci USA 98:1224512250. https://doi.org/10.1073/pnas.211412398

100. Mattson MP, Gleichmann M, Cheng A (2008) Mitochondria in neuroplasticity and neurological disorders. Neuron 60:748-766. https://doi.org/10.1016/j. neuron.2008.10.010

101. McGeer PL, Itagaki S, Boyes BE, McGeer EG (1988) Reactive microglia are positive for HLA-DR in the substantia nigra of Parkinson's and Alzheimer's disease brains. Neurology 38:1285-1291. https://doi.org/10.1212/wnl.38.8.1285

102. Mclntosh TK, Noble L, Andrews B, Faden Al (1987) Traumatic brain injury in the rat: characterization of a midline fluid-percussion model. Cent Nerv Syst Trauma 4:119-134

103. McIntosh TK, Vink R, Noble L, Yamakami I, Fernyak S, Soares H, Faden AL (1989) Traumatic brain injury in the rat: characterization of a lateral fluidpercussion model. Neuroscience 28:233-244

104. McKee AC, Cantu RC, Nowinski CJ, Hedley-Whyte ET, Gavett BE, Budson AE, Santini VE, Lee HS, Kubilus CA, Stern RA (2009) Chronic traumatic encephalopathy in athletes: progressive tauopathy after repetitive head injury. J Neuropathol Exp Neurol 68:709-735. https://doi.org/10.1097/NEN. 0b013e3181a9d503

105. McKee AC, Gavett BE, Stern RA, Nowinski CJ, Cantu RC, Kowall NW, Perl DP, Hedley-Whyte ET, Price B, Sullivan Cet al (2010) TDP-43 Proteinopathy and Motor Neuron Disease in Chronic Traumatic Encephalopathy. J Neuropathol Exp Neurol 69: 918-929 Doi https://doi.org/10.1097/NEN.0b013e3181ee7d85

106. McKee AC, Robinson ME (2014) Military-related traumatic brain injury and neurodegeneration. Alzheimers Dement 10:S242-S253. https://doi.org/10. 1016/j.jalz.2014.04.003

107. McKee AC, Stein TD, Kiernan PT, Alvarez VE (2015) The neuropathology of chronic traumatic encephalopathy. Brain Pathol 25:350-364. https://doi.org/ 10.1111/bpa.12248

108. Miller IN, Cronin-Golomb A (2010) Gender differences in Parkinson's disease: clinical characteristics and cognition. Mov Disord 25:2695-2703. https://doi. org/10.1002/mds.23388

109. Mondello S, Buki A, Italiano D, Jeromin A (2013) alpha-Synuclein in CSF of patients with severe traumatic brain injury. Neurology 80:1662-1668. https://doi.org/10.1212/WNL.0b013e3182904d43

110. Mougenot AL, Nicot S, Bencsik A, Morignat E, Verchere J, Lakhdar L, Legastelois S, Baron T (2012) Prion-like acceleration of a synucleinopathy in a transgenic mouse model. Neurobiol Aging 33:2225-2228. https://doi.org/ 10.1016/j.neurobiolaging.2011.06.022

111. Moujalled D, Grubman A, Acevedo K, Yang S, Ke YD, Moujalled DM, Duncan C, Caragounis A, Perera ND, Turner BJet al (2017) TDP-43 mutations causing amyotrophic lateral sclerosis are associated with altered expression of RNAbinding protein hnRNP K and affect the Nrf2 antioxidant pathway. Hum Mol Genet 26: 1732-1746 Doi https://doi.org/10.1093/hmg/ddx093

112. Murphy MP, LeVine H (2010) Alzheimer's Disease and the Amyloid-beta Peptide. J Alzheimers Dis 19:311-323. https://doi.org/10.3233/Jad-2009-1221
113. Nakashima-Yasuda H, Uryu K, Robinson J, Xie SX, Hurtig H, Duda JE, Arnold SE, Siderowf A, Grossman M, Leverenz JBet al (2007) Co-morbidity of TDP-43 proteinopathy in Lewy body related diseases. Acta Neuropathol 114: 221229 Doi https://doi.org/10.1007/s00401-007-0261-2

114. Newell E, Shellington DK, Simon DW, Bell MJ, Kochanek PM, Feldman K, Bayir H, Aneja RK, Carcillo JA, Clark RS (2015) Cerebrospinal Fluid Markers of Macrophage and Lymphocyte Activation After Traumatic Brain Injury in Children. Pediatr Crit Care Med 16:549-557. https://doi.org/10.1097/PCC. 0000000000000400

115. Oueslati A (2016) Implication of Alpha-Synuclein Phosphorylation at S129 in Synucleinopathies: What Have We Learned in the Last Decade? J Park Dis 6: 39-51. https://doi.org/10.3233/JPD-160779

116. Peelaerts W, Bousset L, Van der Perren A, Moskalyuk A, Pulizzi R, Giugliano M, Van den Haute C, Melki R, Baekelandt V (2015) alpha-Synuclein strains cause distinct synucleinopathies after local and systemic administration. Nature 522:340-344. https://doi.org/10.1038/nature14547

117. Pletnikova O, West N, Lee MK, Rudow GL, Skolasky RL, Dawson TM, Marsh L, Troncoso JC (2005) A beta deposition is associated with enhanced cortical alpha-synuclein lesions in Lewy body diseases. Neurobiol Aging 26:11831192. https://doi.org/10.1016/j.neurobiolaging.2004.10.006

118. Polymeropoulos MH, Lavedan C, Leroy E, Ide SE, Dehejia A, Dutra A, Pike B, Root H, Rubenstein J, Boyer Ret al (1997) Mutation in the alpha-synuclein gene identified in families with Parkinson's disease. Science 276: 2045-2047

119. Prashar A, Schnettger L, Bernard EM, Gutierrez MG (2017) Rab GTPases in Immunity and Inflammation. Front Cell Infect Microbiol 7:435. https://doi. org/10.3389/fcimb.2017.00435

120. Prediger RD, Matheus FC, Schwarzbold ML, Lima MM, Vital MA (2012) Anxiety in Parkinson's disease: a critical review of experimental and clinical studies. Neuropharmacology 62:115-124. https://doi.org/10.1016/j. neuropharm.2011.08.039

121. Prots I, Grosch J, Brazdis RM, Simmnacher K, Veber V, Havlicek S, Hannappel C, Krach F, Krumbiegel M, Schutz O et al (2018) alpha-Synuclein oligomers induce early axonal dysfunction in human iPSC-based models of synucleinopathies. Proc Natl Acad Sci U S A 115:7813-7818. https://doi.org/ 10.1073/pnas.1713129115

122. Oin Z, Hu D, Han S, Reaney SH, Di Monte DA, Fink AL (2007) Effect of 4hydroxy-2-nonenal modification on alpha-synuclein aggregation. J Biol Chem 282:5862-5870. https://doi.org/10.1074/jbc.M608126200

123. Ramlackhansingh AF, Brooks DJ, Greenwood RJ, Bose SK, Turkheimer FE, Kinnunen KM, Gentleman S, Heckemann RA, Gunanayagam K, Gelosa Get al (2011) Inflammation after trauma: microglial activation and traumatic brain injury. Ann Neurol 70: 374-383 Doi https://doi.org/10.1002/ana.22455

124. Recasens A, Dehay B, Bove J, Carballo-Carbajal I, Dovero S, Perez-Villalba A, Fernagut PO, Blesa J, Parent A, Perier C et al (2014) Lewy body extracts from Parkinson disease brains trigger alpha-synuclein pathology and neurodegeneration in mice and monkeys. Ann Neurol 75:351-362. https:// doi.org/10.1002/ana.24066

125. Rey NL, Petit GH, Bousset L, Melki R, Brundin P (2013) Transfer of human alpha-synuclein from the olfactory bulb to interconnected brain regions in mice. Acta Neuropathol 126:555-573. https://doi.org/10.1007/s00401-0131160-3

126. Richardson JR, Fitsanakis V, Westerink RHS, Kanthasamy AG (2019) Neurotoxicity of pesticides. Acta Neuropathol 138:343-362. https://doi.org/ 10.1007/s00401-019-02033-9

127. Rietdijk CD, Perez-Pardo P, Garssen J, van Wezel RJA, Kraneveld AD (2017) Exploring Break's Hypothesis of Parkinson's Disease. Front Neurol 8: Doi ARTN 37. https://doi.org/10.3389/fneur.2017.00037

128. Rolfe DF, Brown GC (1997) Cellular energy utilization and molecular origin of standard metabolic rate in mammals. Physiol Rev 77:731-758. https://doi. org/10.1152/physrev.1997.77.3.731

129. Sacino AN, Brooks M, Thomas MA, McKinney AB, Lee S, Regenhardt RW, McGarvey NH, Ayers Jl, Notterpek L, Borchelt DR et al (2014) Intramuscular injection of alpha-synuclein induces CNS alpha-synuclein pathology and a rapid-onset motor phenotype in transgenic mice. Proc Natl Acad Sci U S A 111:10732-10737. https://doi.org/10.1073/pnas.1321785111

130. Sato K, Hatano T, Yamashiro K, Kagohashi M, Nishioka K, Izawa N, Mochizuki H, Hattori N, Mori H, Mizuno Yet al (2006) Prognosis of Parkinson's disease: time to stage III, IV, V, and to motor fluctuations. Mov Disord 21: 1384-1395 Doi https://doi.org/10.1002/mds.20993

131. Sauerbeck A, Hunter R, Bing G, Sullivan PG (2012) Traumatic brain injury and trichloroethylene exposure interact and produce functional, histological, 
and mitochondrial deficits. Exp Neurol 234:85-94. https://doi.org/10.1016/j. expneurol.2011.12.012

132. Sawada M, Imamura K, Nagatsu T (2006) Role of cytokines in inflammatory process in Parkinson's disease. J Neural Transm Suppl:373-381. https://doi. org/10.1007/978-3-211-45295-0_57

133. Saykally JN, Ratliff WA, Keeley KL, Pick CG, Mervis RF, Citron BA (2018) Repetitive Mild Closed Head Injury Alters Protein Expression and Dendritic Complexity in a Mouse Model. J Neurotrauma 35:139-148. https://doi.org/ 10.1089/neu.2017.5070

134. Schimmel SJ, Acosta S, Lozano D (2017) Neuroinflammation in traumatic brain injury: A chronic response to an acute injury. Brain Circ 3:135-142. https://doi.org/10.4103/bc.bc_18_17

135. Schneider $L$ (2020) A resurrection of aducanumab for Alzheimer's disease. Lancet Neurol 19:111-112. https://doi.org/10.1016/S1474-4422(19)30480-6

136. Sengupta U, Guerrero-Munoz MJ, Castillo-Carranza DL, Lasagna-Reeves CA, Gerson JE, Paulucci-Holthauzen AA, Krishnamurthy S, Farhed M, Jackson GR, Kayed R (2015) Pathological Interface Between Oligomeric Alpha-Synuclein and Tau in Synucleinopathies. Biol Psychiatry 78:672-683. https://doi.org/10. 1016/j.biopsych.2014.12.019

137. Sengupta U, Nilson AN, Kayed R (2016) The Role of Amyloid-beta Oligomers in Toxicity, Propagation, and Immunotherapy. Ebiomedicine 6:42-49. https://doi.org/10.1016/j.ebiom.2016.03.035

138. Shen XT, Chen JM, Li UL, Kofler J, Herrup K (2016) Neurons in Vulnerable Regions of the Alzheimer's Disease Brain Display Reduced ATM Signaling. Eneuro:3. https://doi.org/10.1523/Eneuro.0124-15.2016

139. Shimozawa A, Ono M, Takahara D, Tarutani A, Imura S, Masuda-Suzukake M, Higuchi M, Yanai K, Hisanaga SI, Hasegawa M (2017) Propagation of pathological alpha-synuclein in marmoset brain. Acta Neuropathol Commun 5:12. https://doi.org/10.1186/s40478-017-0413-0

140. Shohami E, Shapira Y, Cotev S (1988) Experimental closed head injury in rats: prostaglandin production in a noninjured zone. Neurosurgery 22:859-863

141. Smith DH, Soares HD, Pierce JS, Perlman KG, Saatman KE, Meaney DF, Dixon CE, McIntosh TK (1995) A model of parasagittal controlled cortical impact in the mouse: cognitive and histopathologic effects. J Neurotrauma 12:169178. https://doi.org/10.1089/neu.1995.12.169

142. Snyder EM, Nong Y, Almeida CG, Paul S, Moran T, Choi EY, Nairn AC, Salter MW, Lombroso PJ, Gouras GK et al (2005) Regulation of NMDA receptor trafficking by amyloid-beta. Nat Neurosci 8:1051-1058. https://doi.org/10. 1038/nn1503

143. Spillantini MG, Crowther RA, Jakes R, Hasegawa M, Goedert M (1998) alphaSynuclein in filamentous inclusions of Lewy bodies from Parkinson's disease and dementia with lewy bodies. Proc Natl Acad Sci U S A 95:6469-6473. https://doi.org/10.1073/pnas.95.11.6469

144. Steger M, Tonelli F, Ito G, Davies P, Trost M, Vetter M, Wachter S, Lorentzen E, Duddy G, Wilson S et al (2016) Phosphoproteomics reveals that Parkinson's disease kinase LRRK2 regulates a subset of Rab GTPases. Elife 5. https://doi.org/10.7554/eLife.12813

145. Stewart W, Allinson K, Al-Sarraj S, Bachmeier C, Barlow K, Belli A, Burns MP, Carson A, Crawford F, Dams-O'Connor Ket al (2019) Primum non nocere: a call for balance when reporting on CTE. Lancet Neurol 18: 231-233 Doi https://doi.org/10.1016/S1474-4422(19)30020-1

146. Stocchetti N, Zanier ER (2016) Chronic impact of traumatic brain injury on outcome and quality of life: a narrative review. Crit Care 20:148. https://doi. org/10.1186/s13054-016-1318-1

147. Su E, Bell MJ, Wisniewski SR, Adelson PD, Janesko-Feldman KL, Salonia R, Clark RS, Kochanek PM, Kagan VE, Bayir H (2010) alpha-Synuclein levels are elevated in cerebrospinal fluid following traumatic brain injury in infants and children: the effect of therapeutic hypothermia. Dev Neurosci 32:385395. https://doi.org/10.1159/000321342

148. Sundman MH, Hall EE, Chen NK (2014) Examining the relationship between head trauma and neurodegenerative disease: A review of epidemiology, pathology and neuroimaging techniques. J Alzheimers Dis Parkinsonism 4. https://doi.org/10.4172/2161-0460.1000137

149. Tan XL, Sun MJ, Brady RD, Liu SJ, Llanos R, Cheung S, Wright DK, CasillasEspinosa PM, Sashindranath M, O'Brien TJ et al (2019) Transactive Response DNA-Binding Protein 43 Abnormalities after Traumatic Brain Injury. J Neurotrauma 36:87-99. https://doi.org/10.1089/neu.2017.5491

150. Tartaglia MC, Hazrati LN, Davis KD, Green REA, Wennberg R, Mikulis $D$, Ezerins $L$, Keightley M, Tator C (2014) Chronic traumatic encephalopathy and other neurodegenerative. Front Hum Neurosci 8: Doi ARTN 30. https:// doi.org/10.3389/fnhum.2014.00030
151. Taylor CA, Bell JM, Breiding MJ, Xu L (2017) Traumatic Brain Injury-Related Emergency Department Visits, Hospitalizations, and Deaths - United States, 2007 and 2013. MMWR Surveill Summ 66:1-16. https://doi.org/10.15585/ mmwr.ss6609a1

152. Tobin JE, Latourelle JC, Lew MF, Klein C, Suchowersky O, Shill HA, Golbe LI, Mark MH, Growdon JH, Wooten GF et al (2008) Haplotypes and gene expression implicate the MAPT region for Parkinson disease - The GenePD Study. Neurology 71:28-34. https://doi.org/10.1212/01.wnl.0000304051.01650.23

153. Uryu K, Giasson BI, Longhi L, Martinez D, Murray I, Conte V, Nakamura M, Saatman K, Talbot K, Horiguchi T et al (2003) Age-dependent synuclein pathology following traumatic brain injury in mice. Exp Neurol 184:214-224. https://doi.org/10.1016/s0014-4886(03)00245-0

154. Uversky VN, Eliezer D (2009) Biophysics of Parkinson's disease: structure and aggregation of alpha-synuclein. Curr Protein Pept Sci 10:483-499

155. Velazquez A, Ortega M, Rojas S, Gonzalez-Olivan FJ, Rodriguez-Baeza A (2015) Widespread microglial activation in patients deceased from traumatic brain injury. Brain Inj 29:1126-1133. https://doi.org/10.3109/02699052.2015.1018325

156. Volpicelli-Daley LA, Abdelmotilib H, Liu Z, Stoyka L, Daher JP, Milnerwood AJ, Unni VK, Hirst WD, Yue Z, Zhao HT et al (2016) G2019S-LRRK2 Expression Augments alpha-Synuclein Sequestration into Inclusions in Neurons. J Neurosci 36:7415-7427. https://doi.org/10.1523/JNEUROSCI.3642-15.2016

157. Volpicelli-Daley LA, Kirik D, Stoyka LE, Standaert DG, Harms AS (2016) How can rAAV-alpha-synuclein and the fibril alpha-synuclein models advance our understanding of Parkinson's disease? J Neurochem 139(Suppl 1):131-155. https://doi.org/10.1111/jnc.13627

158. Wang HK, Lee YC, Huang CY, Liliang PC, Lu K, Chen HJ, Li YC, Tsai KJ (2015) Traumatic Brain Injury Causes Frontotemporal Dementia and Tdp-43 Proteolysis. Neuroscience 300:94-103. https://doi.org/10.1016/j.neuroscience.2015.05.013

159. Wang Q, Liu Y, Zhou J (2015) Neuroinflammation in Parkinson's disease and its potential as therapeutic target. Transl Neurodegener 4:19. https://doi.org/ 10.1186/s40035-015-0042-0

160. Wang X, Becker K, Levine N, Zhang M, Lieberman AP, Moore DJ, Ma J (2019) Pathogenic alpha-synuclein aggregates preferentially bind to mitochondria and affect cellular respiration. Acta Neuropathol Commun 7:41. https://doi. org/10.1186/540478-019-0696-4

161. Webb JL, Ravikumar B, Atkins J, Skepper JN, Rubinsztein DC (2003) AlphaSynuclein is degraded by both autophagy and the proteasome. J Biol Chem 278:25009-25013. https://doi.org/10.1074/jbc.M300227200

162. Williams AJ, Hartings JA, Lu XC, Rolli ML, Tortella FC (2006) Penetrating ballistic-like brain injury in the rat: differential time courses of hemorrhage, cell death, inflammation, and remote degeneration. J Neurotrauma 23: 1828-1846. https://doi.org/10.1089/neu.2006.23.1828

163. Woodcock T, Morganti-Kossmann MC (2013) The role of markers of inflammation in traumatic brain injury. Front Neurol 4:18. https://doi.org/10. 3389/fneur.2013.00018

164. Wright DK, Liu SJ, van der Poel C, McDonald SJ, Brady RD, Taylor L, Yang L, Gardner AJ, Ordidge R, O'Brien TJ et al (2017) Traumatic Brain Injury Results in Cellular, Structural and Functional Changes Resembling Motor Neuron Disease. Cereb Cortex 27:4503-4515. https://doi.org/10.1093/cercor/bhw254

165. Xiong Y, Mahmood A, Chopp M (2013) Animal models of traumatic brain injury. Nat Rev Neurosci 14:128-142. https://doi.org/10.1038/nrn3407

166. Yang ZH, Lin F, Robertson CS, Wang KKW (2014) Dual vulnerability of TDP43 to calpain and caspase-3 proteolysis after neurotoxic conditions and traumatic brain injury. J Cerebr Blood F Met 34:1444-1452. https://doi.org/ 10.1038/jcbfm.2014.105

167. Zarranz JJ, Alegre J, Gomez-Esteban JC, Lezcano E, Ros R, Ampuero I, Vidal L, Hoenicka J, Rodriguez O, Atares Bet al (2004) The new mutation, E46K, of alpha-synuclein causes Parkinson and Lewy body dementia. Ann Neurol 55: 164-173 Doi https://doi.org/10.1002/ana.10795

168. Zhao Y, Perera G, Takahashi-Fujigasaki J, Mash DC, Vonsattel JPG, Uchino A, Hasegawa K, Jeremy Nichols R, Holton JL, Murayama S et al (2018) Reduced LRRK2 in association with retromer dysfunction in post-mortem brain tissue from LRRK2 mutation carriers. Brain 141:486-495. https://doi.org/10.1093/ brain/awx344

169. Zohar O, Schreiber S, Getslev V, Schwartz JP, Mullins PG, Pick CG (2003) Closed-head minimal traumatic brain injury produces long-term cognitive deficits in mice. Neuroscience 118:949-955

\section{Publisher's Note}

Springer Nature remains neutral with regard to jurisdictional claims in published maps and institutional affiliations. 